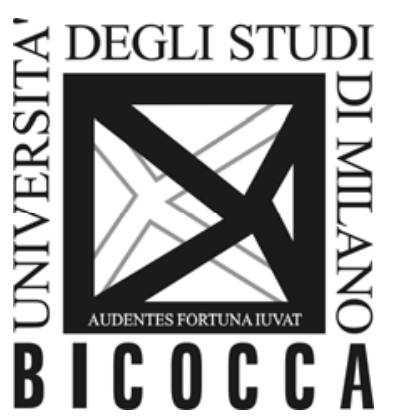

\author{
DEPARTMENT OF ECONOMICS, \\ MANAGEMENT AND STATISTICS \\ UNIVERSITY OF MILAN - BICOCCA
}

DEMS WORKING PAPER SERIES

\title{
The cost of default: private vs. official sovereign debt restructurings
}

\author{
Silvia Marchesi
}

No. 320 - December 2015

Dipartimento di Economia, Metodi Quantitativi e Strategie di Impresa Università degli Studi di Milano - Bicocca

http://dems.unimib.it/ 


\title{
The cost of default: private vs. official sovereign debt restructurings
}

\author{
Silvia Marchesi \\ University of Milano Bicocca and Centro Luca d'Agliano*
}

December 2015

\begin{abstract}
This paper studies the relationship between sovereign debt default and (short term) GDP growth taking into account the depth of a debt restructuring and distinguishing between commercial and official sovereign debt restructurings. Analyzing default episodes in 117 countries over the period 1975-2013, I find that, in the short term, defaults are correlated with significant contraction of output growth. Moreover, by controlling for both the occurrence and the magnitude of private and official defaults, I am able to detect a more lasting and negative link between default and growth (which eventually turns out to be positive but only for haircuts). In both cases I find evidence of a trade-off concerning the restructuring's size. Higher haircuts, however, may have some benefits in the short-run, but in turn imply a negative stigma which lower growth over a longer period. Conversely, higher amount of official restructuring may have some costs in the short-run, but are associated to an increase in growth in the long run. Adopting an alternative specification, in which the dependent variable is a country's credit rating, I investigate whether variation in the borrowing costs (highly correlated with credit ratings) may be one of the channels behind the link between restructuring and growth. I find that, in the case of haircuts, an improvement in the borrowing conditions a few years after the restructuring may explain a growth recovery. For official restructurings the evidence is more mixed.
\end{abstract}

Keywords: Haircuts, Output losses, Sovereign defaults

JEL Classification: F34, G15, H63

${ }^{*}$ I thank Peter Claeys, Arben Kita and participants to the 6th International Conference on Economics of Global Interactions (Bari University, 2015) and to the 24th International Rome Conference on Money Banking and Finance (LUMSA University, 2015) for helpful comments. I would like to thank Federico Bestetti for excellent research assistance. Silvia Marchesi, Dipartimento di Economia Politica, Piazza Ateneo Nuovo 1, I-20126 Milano. Tel. +39 02 64483057; Fax. +39 02 64483085; E-mail: silvia.marchesi@unimib.it. 


\section{Introduction}

Sovereign debt problems and debt restructuring have traditionally been topical for emerging economies in light of the debt crisis of the early 1980s and 1990s. The European sovereign debt crisis, especially after the recent events in Greece, has renewed the debate on sovereign debt restructuring (and debt relief) for developed economies as well (e.g., Zettelmeyer et al. 2013).

Sovereign defaults and debt restructuring are not costless as a sovereign's unilateral decisions to stop servicing its debt implies important economic costs. At least this is what the sovereign debt literature has commonly assumed as a government's main incentive to honor its debt obligations. In sovereign debt theory defaults maybe costly due to direct punishment (mainly trade sanctions), capital market exclusion or higher cost of borrowing (the so called reputational effect) or mainly domestic costs, which in turn depend on negative spillovers on corporate access to foreign credit, investments and trade (Bulow and Rogoff 1989a, Cole et al. 1995, Eaton and Gersovitz 1981, Sandleris 2008, Mendoza and Yue 2012). ${ }^{1}$

The (empirical) literature analyzing sovereign defaults has mainly looked at their effects on international trade, international credit market and GDP growth. There is evidence documenting trade cost of defaults in particular for export-oriented industries (Rose 2005, Borensztein and Panizza 2010). Apparently the access to credit market is influenced by more recent repayments but not by distant repayment history (e.g., Ozler 1993), which is also confirmed in more recent papers documenting a short-lived effect of default on spreads and market access (Borensztein and Panizza 2009, Gelos et al. 2011 and Panizza et al. 2009). ${ }^{2}$ Only very recently, Cruces and Trebesch (2013a) came to different conclusions, which are more in line with the effects of a default according to the theory. More specifically, by including in their analysis a measure of investors' losses (or "haircuts"), they show that restructuring involving higher haircuts are associated with significantly higher subsequent bond yield spreads and longer periods of capital market exclusion (that is credit markets do not seem to "forgive and forget," as in Bulow and Rogoff 1989b). Such different result with respect to the previous literature is remarkable and it is attributed to a more precise measurement of a country's repayment record. Therefore, their analysis does suggest that it is crucial to consider the magnitude of a default and not only

\footnotetext{
${ }^{1}$ For a survey see Panizza et al. (2009) and Tomz and Wright (2013).

${ }^{2}$ Studies that instead provide empirical evidence in support to the "reputation view" include English (1996) and Tomz (2007).
} 
its occurrence.

As the direct link between debt default and economic growth is concerned, a strong but short-lived negative contemporaneous effect on GDP growth is found by Sturzenegger (2004) and later confirmed by Borensztein and Panizza (2009) and De Paoli et al. (2006) and (2009). ${ }^{3}$ In all these cases, however, the effects specifically associated with a default (on the top of those related to the crisis itself) are quite difficult to identify. Therefore, while there is evidence that sovereign debt defaults are negatively correlated with economic growth, there is no study finding a causal relationship going from default to growth.

In this paper I focus on the relationship between annual GDP growth and private and official debt restructuring applying a similar methodology to Cruces and Trebesch (2013a) to the analysis of the relationship between debt default and economic growth. ${ }^{4}$ Specifically, I take the creditors' losses as proxy of the severity of the default episode and I verify if higher haircuts are correlated with a significant contraction of (annual) economic growth over a period of ten years. While the overall evidence indicates that default episodes are negatively correlated with growth, in this literature the decision of a default has been modelled as a binary decision ignoring the large variation in restructuring outcomes. ${ }^{5}$

Debt restructuring could affect growth in at least two alternative ways. Higher haircuts (or official restructurings) may have negative effects on growth, as the adverse spillovers of a default are likely to be more severe in hard defaults (i.e., involving higher haircuts) as compared to soft defaults (see Trebesch and Zebel 2014). Alternatively, there is the channel of debt relief operating in the opposite direction. Since higher haircuts (or official restructurings) reduce the level of government's debt more substantially, such debt

\footnotetext{
${ }^{3}$ Using higher frequency data, Levy Yeyati and Panizza (2011) actually show that output contraction precedes default and that default episodes seem actually already to mark the beginning of the economic recovery. Furceri and Zdzienicka (2012) find, instead, long-lasting output losses after debt crises, while Tomz and Wright (2007) find a negative but surprisingly weak relationship between economic output and default on loans from private foreign creditors.

${ }^{4}$ Defined narrowly, default occurs when the debtor violates the legal terms of the debt contract (e.g., the debtor might fail to pay interest or principal within the specified grace period). This narrow definition, however, overlooks situations in which the sovereign threatens to default and creditors respond by "voluntarily" revising the contract. In recognition of this problem, credit ratings agencies like Standard and Poor's define a default as beginning either when the sovereign breaks the contract, or when the sovereign "tenders an exchange offer of new debt with less favorable terms than the original issue" (Beers and Chambers 2007). This broader definition is usually preferred and this the one I adopt in this paper.

${ }^{5}$ The literature has mostly focused on the occurrence of debt crises, but not on their resolution. This circumstance implies, de facto, no distinction between the different degrees of severity of default episodes and could (at least partially) explain why previous literature has so far detected negligible medium-run effects of debt defaults on growth.
} 
reduction might allow countries to exit a debt overhang improving in this way growth prospects, as described by Krugman (1988). The overall impact of a debt restructuring on growth is then theoretically ambiguous and remains an empirical question.

Despite the policy relevance of this issue, little is known about the characteristics and the economic relevance of debt restructuring. ${ }^{6}$ I contribute towards filling this gap by studying the relationship between debt default and annual GDP growth over a ten-year period, by taking into account the depth of a debt restructuring. ${ }^{7}$ Moreover, I analyze separately commercial and official restructurings given the different ability to access the credit market and the different policy implication to solve debt problems of these two types of defaulters. To the best of my knowledge, it is the first time in this literature that the link between GDP growth and debt restructuring is investigated over such a (relatively) long time period, and that the distinction between private and official restructuring is taken into account.

Analyzing default episodes in 117 countries over the period 1975-2013, consistently with previous results, I find that defaults are correlated with significant contraction of shortterm output growth. Moreover, controlling for the severity of the default, I find that a (commercial debt) default is indeed correlated with a further contraction in output up to five years after the default (which is however softened by the size of the haircut) but also with an increase in economic growth ten years after the default (which is however reduced by the haircut size). In the case of official debt restructuring, evidence of correlation between growth and the restructuring is actually weaker in the short run, but there is evidence of a negative correlation between growth and the restructuring dummy seven years after the default (which is however offset by the amount of the restructuring).

More generally, by controlling for both the occurrence and the magnitude of both private and official defaults, I am able to detect a more lasting and negative link between debt default and growth (which eventually turns out to be positive but only for haircut).

\footnotetext{
${ }^{6}$ More recently, however, some attention has been devoted to the specific analysis of debt renegotiations. Among others, Benjamin and Wright 2009, Asonuma and Trebesch (2015), Trebesch and Zebel (2014) and Reinhart and Trebesch (2015) have been specifically focusing on debt crisis resolution and renegotiation.

${ }^{7}$ Trebesch and Zabel (2014), by distinguishing between hard defaults (more confrontational) and soft defaults (adopting a consensual crisis resolutions), show that hard defaults are associated with a much steeper drop in output as compared to soft defaults. Surprisingly, however, after five years, neither high haircuts nor debtor coerciveness are associated with lower growth. Reinhart and Trebesch (2015), focusing only on the amount of debt relief achieved in the samples 1920-1939 and 1978-2010 find that while softer forms of debt relief, (e.g. maturity extensions) are not generally followed by higher economic growth, only debt write-offs are able to improve the economic situation of debtor countries.
} 
In both cases, occurrence and magnitude of default go into opposite direction and in both cases I find evidence of a trade-off concerning the amount of the restructured debt. However, while high haircuts have some benefits in the short-run (but in turn imply some negative stigma which somehow lowers growth over a longer period), higher amount of official restructuring may have some costs in the short-run, but are associated to an increase in GDP growth in the long run. No stigma is associated to the size of the official restructuring, indeed defaulters seem to benefit from the debt relief effect of high restructurings (as in Arslanalp and Henry 2005), which mitigate the negative consequences of an official default and improves recovery.

Finally, in an alternative specification, in which the dependent variable is a country's credit rating, I investigate whether one of the channels explaining the link between restructuring and growth may work through the capital market (or reputational effect). As above, I find different results in the case of haircuts with respect to official restructurings.

In the case of haircuts, my results confirm that one of the channels leading to a growth recovery may be due to an improvement in the borrowing conditions (which highly correlate with credit ratings). The perception of private investors is improving after a few years since the restructuring episode, even if higher haircuts are associated to higher ratings up to five years after the default (as in Cruces and Trebesch 2013a). For official restructurings the evidence is more blurred. In particular, credit rating and official restructuring seem to be correlated only in the short term and defaulting on official debt seems overall less costly over a longer period. To my knowledge, it is the first time that both the occurrence and the magnitude of a restructuring are considered as possible determinants of a country's credit ratings.

The rest of this paper is organized as follows. Section 2 describes the empirical model and the data while the results are presented in Section 3. Section 4 describes some robustness checks while section 5 presents the results of an alternative specification in which the dependent variable is a country's credit rating. Finally, Section 6 summarizes and concludes.

\section{Data and empirical model}

In this section, I analyze the effects of a debt default on economic growth by controlling for the severity of the default episode. For this reason I include both a measure of private 
creditors' losses (the so called haircuts) and a measure of official restructurings (Paris Club debt restructurings) as proxies for the magnitude of both private and official defaults.

\subsection{Default coding and sample composition}

Our analysis spans the years between 1975 and 2013 and includes 117 developing and emerging market economies. ${ }^{8}$ I have selected this sample as follows. First, I excluded from the sample small countries with a population of less than 1 million (as measured at the end of the sample period in 2013) and all advanced economies, in order to make the sample as homogeneous as possible. Moreover, I dropped countries whose debt restructurings took place in the context of wars and state dissolution, such as Iraq, and successor states of the Socialist Republic of Yugoslavia (i.e., Kosovo, Macedonia, Bosnia and Herzegovina and Serbia). The resulting set of 117 countries includes 73 defaulting countries, which experienced at least one debt crisis during the sample period as well as 44 non-defaulters. Among defaulters, 55 countries had only commercial debt restructurings (through haircuts), while 18 countries had only official debt restructurings (through the Paris Club). ${ }^{9}$ Table A1 in the Appendix shows all countries and years, including a list of debt crisis episodes studied here.

Table 1 shows summary statistics for different subsamples in the full sample of 150 restructurings. I find that the average haircut between 1975 and 2013 is about 39 percent (simple mean). Looking at the three different subperiods, I detect a sizeable increase in the haircut size over time. Average haircut is about 39 percentage points higher during the last subperiod (2002-2013) as compared to haircuts implemented during the initial period (1975-1988) but only about 11 percentage points higher with respect to the intermediate one (1989-2001). One reason is that all the deals up to the beginning of the Brady plan (1989-1994) mainly implied maturity extensions without an actual debt reduction. ${ }^{10}$ Figure 1 shows the frequency distribution of haircuts by percentage size.

I relied on the original dataset by Cruces and Trebesch (2013b) for the data on restruc-

\footnotetext{
${ }^{8}$ More specifically, following the 2013 World Bank Country classification, we have included low, middle income and high income (non OECD) countries.

${ }^{9} 51$ countries of the sample had instead both their commercial and official debt restructured.

${ }^{10}$ In the late 1980s (1989-1994), Brady deals addressed commercial bank lending to sovereign debtors (mostly middle-income countries) involving a combination of an IMF agreement and debt-service reduction and rescheduling from commercial banks. Brady deals, which eventually put an end to the 1980s debt crisis for 17 debtor countries, involved an average haircut of 45 percent (Cruces and Trebesch 2013).
} 
turings with foreign banks and bondholders (commercial creditors). ${ }^{11}$ More specifically, the database of investor losses built by Cruces and Trebesch (2013b) is based on the methodology proposed by Sturzenegger and Zettelmeyer (2008) and consider haircuts in "final" debt restructurings only. Final deals are those that enable countries to cure the default and exit a crisis spell without a renewed default in the following 4 years. This focus on final restructurings is in the spirit of related work such as Cline (1995), Arslanalp and Henry (2005) and Reinhart and Trebesch (2015) who also study the outcome of final deals and pay less attention to intermediate restructurings like most debt operations of the 1980 s. $^{12}$

Cruces and Trebesch then define haircuts as:

$$
H_{s z}=1-\frac{\text { Present value of New Debt }\left(r_{t}^{i}\right)}{\text { Present value of Old Debt }\left(r_{t}^{i}\right)}
$$

where $r_{t}^{i}$ is the discount factor employed to calculate the present value of old and new debt instruments. ${ }^{13}$

Finally, for official debt restructurings, I relied on the original dataset built by Das et al. (2011) which contains a list of sovereign debt restructurings with the Paris Club (between 1950 and 2010). ${ }^{14}$ Paris Club creditors may provide (official ) debt treatments to debtor countries in the form of rescheduling (i.e., debt relief by postponement) or, in the case of concessional rescheduling, reduction in debt service obligations during a defined period (flow treatment) or as of a set date (stock treatment).

Table 1 also shows summary statistics for different subsamples in the full sample of 355 restructurings. I find that the average value over the years 1975-2013 is about 11 percent, thus resulting much more frequent but much lower that the average haircut. Looking at the three different subperiods, I find a sizeable increase in the size of official restructurings over time. Average size is about 25 percentage points higher during the last subperiod (2002-2013), as compared to restructurings implemented during the years (1989-2001).

\footnotetext{
${ }^{11}$ In August 2014, the authors provided an update of their data covering the year 2013 as well. Their data provides a list of 187 distressed sovereign debt restructurings with external private creditors (banks and bondholders) occurring between 1970 and 2013.

${ }^{12}$ Examples of final restructurings include the Brady debt exchanges of the 1990s as well as all main recent emerging market bond exchanges such as Russia 2000 or Argentina 2005.

${ }^{13}$ While prior literature used a constant average rate for each restructuring, Sturzenegger and Zettelmeyer set-up a restructuring-specific discount rate, $r_{t}^{i}$, dataset (not country-specific), which is computed by the specific country situation and by the level of credit risk premium at that time.

${ }^{14}$ This dataset was last updated in November 2012.
} 
Similarly, it is 21 percentage points higher during the intermediate subperiod (1989-2001), with respect to the initial one. ${ }^{15}$ Figure 2 finally shows the frequency distribution of official restructuring by percentage size.

\section{TABLE 1 HERE}

\section{FIGURE 1 \& FIGURE 2 HERE}

\subsection{Method}

In this subsection, I analyze the relationship between private and official restructuring and annual per capita GDP growth over the 1975-2013 period. I obtain an unbalanced panel which comprises a maximum of 117 developing countries, depending on the control variables I include. I adopt a robust OLS fixed effects estimator in order to control for country unobservable and to correct for heteroskedasticity.

Specifically I test:

$$
y_{i t}=\alpha+\beta X_{i t}+\gamma_{j} R_{i t+j}+\delta_{j} D_{i t+j}+\eta_{i}+\tau_{t}+u_{i t}, \quad j=-1, \ldots .,+10
$$

where $y_{i t}$ represents per capita growth in country $i$ at period $t, R_{i t+j}$ is the amount restructured (private or official) associated to the default of the year $t$ in country $i$, $D_{i t+j}$ is an indicator variable equal to one when country $i$, in year $t$, has finalized its last restructuring, and $X$ is a vector containing my control variables.

I then generated twelve variables denoting the anticipated default, current default and up to ten leads of each default episode; and twelve more variables denoting the haircut (and the official restructuring) at $t-1, t$ and up to ten years following the sovereign debt restructuring. Finally, $\eta_{i}$ and $\tau_{t}$ denote country and time dummies, respectively, which allow us to control for both countries unobservable and time invariant variation and common trends. ${ }^{16}$

\footnotetext{
${ }^{15}$ As low-income countries are concerned, Paris Club creditors agreed to provide them concessional reschedulings (conditional on the adoption of an IMF program) under the Toronto (1988), Trinidad (1990), Naples terms (1994). In 1996, the World Bank and the IMF have implemented the Heavily Indebted Poor Countries (or HIPC) Debt Initiative, which was first strengthened in 1999, and more recently in 2005, when, under the Multilateral Debt Relief Initiative (MDRI) multilateral institutions were encouraged to increase their specific contribution to debt reduction.

${ }^{16}$ In this way we can also accounts for global factors that might have influenced the simultaneous dating choice of debt restructuring events (e.g., Baker or Brady plan in the two periods, 1985-88, and, 1989-94, respectively).
} 
The advantage of estimating equation (1) is that it allows me to disentangle the growth increase associated with the default per se from the growth increase associated with the size of the haircut: "occurrence" versus "magnitude."

My choice of control variables follows the literature on the impact of default on output growth, in particular I adopt the same specification as in Levy Yeyati and Panizza (2011). More specifically, I control for investments as a percentage of GDP, a measure of openness (exports and imports over GDP), government expenditure, annual rate of growth of population and total population (both in log), rate of variation of annual terms of trade, the percentage of the population that completed secondary education, the Freedom House index of civil liberties and a dummy for a banking crises (Laeven and Valencia 2013).

Table A2 in the Appendix provides a detailed description of each control variable and its source while table A3 shows some summary statistics.

\section{Empirical results}

\subsection{Haircuts}

The results of the model of equation (1) are presented in table 2. In columns 1-3, I report only the coefficients of the haircut dummy, the haircut and of both variables together, in the year of the restructuring, one year before and one year after the default episode without any control variables. ${ }^{17}$ Column 4 reports the same specification of column 3 including control variables. In columns 5-8, I progressively add the coefficients of both the haircut dummies and size (from up to three to up to ten years after the default) to the specification of column 4 . While all these results are reported for comparison, I largely base the discussion on the fully specified model of column $8 .{ }^{18}$

As can be seen, most of the control variables have the expected sign. Growth rates significantly increases with higher investment and higher terms of trade, while it decreases with higher population (in log), higher public expenditure and after the occurrence of a

\footnotetext{
${ }^{17}$ We should be aware that the results of columns 1 and 2 do not allow differentiating between the growth variation associated with a restructuring and that associated with the size of the haircut. In particular equation 2 is problematic as it only includes the interacted variable $\left(R_{i t+j}\right)$ but not the constitutive term $\left(D_{i t+j}\right)$ (Cruces and Trebesch 2013).

${ }^{18}$ The best way to interpret the findings of table 1 is to consider the expected variation in growth as conditional on the haircut size, that is $\gamma_{j} R_{i t+j}+\delta_{j}$.
} 
banking crisis. The coefficients of population growth, openness, and civil liberties are not significant. ${ }^{19}$

As our variables of interests are concerned, in column 8, we can observe that the relationship between growth and the haircut dummy has always the opposite sign with respect to that with the haircut size. More specifically, if we look at the short-term link between growth and private restructuring, while the anticipation of a restructuring deal is perceived as a positive event (growth increases by 3.5 percent at time $t-1$ ), anticipation of a higher amount of private restructuring is perceived negatively (an increase of one standard deviation in the haircut decreases growth by about 0.50 percent). After the default materializes, however, we observe the opposite. One year after the default, the coefficient of the haircut dummy becomes negative and significant at the five-percent level (growth decreases by almost 2 percent at time $t+1$ ), while an increase of one standard deviation in the size of the haircut is associated with an increases in growth by about 0.34 pecent. Instead, current levels of both the haircut dummy and its size seem not to be related to growth. ${ }^{20}$

In the longer run the correlation between the occurrence of a private restructuring and growth remains negative up to the fifth years after the default episode. In particular, the results of column 7 show that the coefficient of the haircut dummy is negative, and significant at the ten-percent level, also in the fifth year after a default (but in this case independently of the size of the haircut). Specifically, the simple event of a private debt restructuring reduces growth by about 1.77 percent. ${ }^{21}$

Moreover, I can detect some positive correlation between growth and the restructuring in the tenth year after the default, which is however mitigated by the amount of the restructured debt. In particular, the simple event of a private debt restructuring increase growth by 1.75 percent while an increase of one standard deviation in the haircut decreases growth by about 0.34 percent. $^{22}$

\footnotetext{
${ }^{19}$ These results are indeed quite similar to those obtained by Levy Yeyati and Panizza (2011).

${ }^{20}$ Evidence of a short-term relationship between growth and private restructuring (both haircut dummy and size) is confirmed also in the specifications shown in colums 1-7.

${ }^{21}$ In column 6 the coefficient of the fifth lead is also negative and significant at conventional levels, while in the last column it remains negative but not anymore significant at a conventional level ( $\mathrm{p}$-value $0.16)$.

${ }^{22}$ Such positive effect could be explained by the circumstance that the government of the indebted country decides to implement structural policy reforms (that at least to some extent "come" with the restructuring) which may speed up recovery from an existing recession.
} 
To sum up, while in the short run I find that the anticipation of a restructuring deal is perceived as positive (but such effect is mitigated by the anticipation of a greater haircut), once the default (and the haircut) actually materializes, this event is correlated with a significant contraction in growth which is however softened by the haircut. Correlation between private restructuring and growth remains negative up to the fifth years after the default episode (independently of the haircut) and eventually turns out to be positive ten years after the default. However, in this case the haircuts seem to represent a negative stigma for the countries involved. More generally, these results can be interpreted as evidence for the existence of a trade-off: high haircuts may have some benefits in the short-run, but in turn they may also imply some negative (reputational) costs which lower growth over a longer period somehow delaying recovery.

Our results are to some extent similar to those of Cruces and Trebesch (2013a). As they do, by controlling for both the occurrence and the magnitude of (private) default I am able to detect a more lasting (and negative) link between debt default and growth. Furthermore, by adding more leads, I am eventually able to detect a positive correlation between growth and the haircut dummy up to ten years after the default. What I find is instead different from the results of Trebesch and Zebel (2014) which do not detect any evidence of a reduction in GDP growth in the aftermath of a default (in particular after five year from the default episodes). ${ }^{23}$ Our results are also different from Levy Yeyati and Panizza (2011) who show that output contractions actually precede default and that default episodes seem already to mark the beginning of the economic recovery.

I should emphasize, however, that the results in this section should be taken cautiously. In particular, they do not imply that imposing high haircuts have a long-lasting effects on growth. As I have explained, identification is difficult and there are competing channels, which are hard to disentangle in the data at hand. Moreover, it is possible that the timing of the restructuring is endogenous, which may bias the haircut coefficient. ${ }^{24}$

\section{TABLE 2 HERE}

\footnotetext{
${ }^{23}$ They include, however, only a constant 5-year lead measure.

${ }^{24}$ Indeed, both sovereigns and creditors may have an incentive to settle in good times, when default risk is low and growth prospects are good (as shown by Benjamin and Wright, 2009).
} 


\section{$3.2 \quad$ Official Restructurings}

The results for official restructurings are presented in table 3. Columns 1-3 of table 3 report only the coefficients of the official restructuring dummy, the official restructuring size and of both variables together in the year of the default, one year before and after the default episode, respectively, without any control variables. Column 4 reports the same specification of column 3 including control variables. In columns 5- 8, I progressively add, to the specification of column 4 , the coefficients of both the official restructuring dummies and size from up to three to up to ten years after the default. As above, I largely base our discussion on the fully specified model of column 8 .

As before, most of our control variables have the expected impact on growth. As our variables of interests are concerned, the evidence of a correlation between official restructuring and economic growth is overall much weaker than in the case of private creditors.

Looking at column 8 of table 3 we observe that the evidence of a correlation between growth and official restructuring is actually weaker in the short run. The only coefficient to be significant, at ten-percent levels, is that of the contemporaneous amount of official restructuring. The simple occurrence of a restructuring is hardly significant (p-value 0.14) and with a positive sign, while the amount of official restructuring negatively correlates with growth (in particular an increase of one standard deviation in the amount of official restructuring reduces growth by about 0.68 percent). ${ }^{25}$

Conversely, in the long run, there is evidence of a negative correlation between growth and the official restructuring dummy seven years after the default, which is however mitigated by the amount of the restructured debt. In particular the simple event of an official debt restructuring growth by 1.45 percent while an increase of one standard deviation in the amount of official restructuring increases growth by about 0.52 percent. ${ }^{26}$

The trade off I have described in the previous section now acts in the opposite way as before: higher amount of official restructuring may have some (social and political costs) in the short-run, but eventually they imply some positive effects over the long term, as the debt relief effect of high restructurings seems to improves recovery by freeing up new resources. As before, however, controlling for the severity of the default through the amount of official restructurings, allows me to detect a more lasting (and negative) link between

\footnotetext{
${ }^{25}$ I can detect similar results to those of table 2 only looking at columns 1-3 of table 3.

${ }^{26}$ These results are robust to a specification in which we excluded HIPC, which are available on request.
} 
debt default and growth which is however mitigated by the size of the restructuring. No stigma is now associated to the size of the restructuring, indeed defaulters seem to benefit from the debt relief effect of high restructurings (as in Arslanalp and Henry, 2005), which possibly mitigate the negative consequences of an official default.

\section{TABLE 3 HERE}

\section{Robustness checks}

This section aims to test the robustness of our main model of equation (1). More specifically, I try to control for the presence of (i) autocorrelated standard errors (ii) omitted variable bias, as common shocks could affect both output and haircuts, and (iii) reverse causality, since changes in output can potentially explain the type of default.

I address concerns of serially correlated errors by including lagged growth in my specification. As the omitted variable bias is concerned, I include country and time fixed effects and many economic and political control variables, such as the standard macro controls used in the growth literature, including banking and currency crises, and political risk. Finally, to check for reverse causality, I also test the influence of lagged growth on our explanatory variables. All these results are shown in table 4 .

Autocorrelated standard errors. One way to address this problem, is to add a lagged value of the dependent variable. In a dynamic panel with country fixed effects the lagged dependent variable is correlated with the country-specific component of the error term and, thus, the OLS fixed-effects estimator produces biased estimates. However, Nickell (1981) shows that, in the AR(1) case, the bias declines as the time series dimension of the panel, $T$, increases. Judson and Owen (1999) testing the performance of the fixed-effects estimator on panels with typical macroeconomic dimensions find that the fixed-effects estimator performs well when $T=30$. As in our sample $T=39$, we expect any bias introduced by the inclusion of the lagged dependent variable to be very small. I then include growth at time $(t-1)$, in columns 1-2 and 5-6 of table 4 and, as can be seen, both sign and significance of the restructuring variables remain the same.

Additional controls. The results could still be biased due to the omission of timevarying country-specific variables correlated with both growth and the government payment behavior and growth, despite controlling for time and country fixed effects and 
standard macro controls. More specifically, following Trebesch and Zebel (2014), I include political risk (as debtor payment attitude may be affected by political crises) and control for the occurrence of currency crises (as well as the occurrence of banking crises). ${ }^{27}$ Thus, I add the ICRG political risk indicator as well as a dummy for changes in the executive (taken from the Database of Political Institutions, DPI). Moreover, I also include inflation and the debt to GDP ratio, both taken form the World Development Indicators (WDI).

In columns 3-4 and 7-8 of table 4 I have then included additional controls, which, however, are available only for a reduced sample. As the number of observations drops dramatically (by almost half) these results are hardly comparable as changes in the coefficients of the interest variables might be due to changes in sample size rather than to their different effect. Nevertheless, the results are overall similar to those of previous specifications.

Reverse causality. Reverse causality can indeed be one of the main objection to comment our result. Therefore, I test the influence of lagged growth on our explanatory variables. Table 5 reports the results in the case of private restructurings. More specifically, in columns 1-3 of table 5 I test the influence of lagged growth on the current level of haircut, in columns 4-6 I test the influence of lagged growth on the level of haircut at time $(t+1)$, while in columns 7-9 the dependent variable is the level of haircut at $(t+5)$. In all specifications I do not find any evidence that lagged growth is a good predictor for haircut.

Table 6 reports the results in the case of official restructurings. In columns 1-3 of table 6 I test the influence of lagged growth on the current level of official restructuring, in columns 4-6 I test the influence of lagged growth on the level of official restructuring at time $(t+1)$, while in columns 7-9 the dependent variable is the level of official restructuring at $(t+5)$. Also in this case there is no evidence that lagged growth helps to predict official restructurings.

Taken together, I find no evidence for reverse causality and no evidence for a confounder driving our main results. Nevertheless, I should be interpret our result with caution as I cannot detect any causal effect but only strong conditional correlations.

\section{TABLE 4,5 \& 6 HERE}

\footnotetext{
${ }^{27}$ Both indicators are taken from Laeven and Valencia (2013).
} 


\section{Credit ratings}

In this section we investigate whether one of the channels explaining the link between restructuring and growth may work through the capital market. More specifically, adopting an alternative specification in which the dependent variable is a country's credit rating should allow me to investigate whether variations in the borrowing costs (represented by variation in the credit ratings) could, at least partially, explain corresponding variations in GDP growth.

Studies that measured the impact of default on borrowing costs have focused on both direct and indirect measures, the main indirect measure being a country's credit rating. This is a relevant measure because credit ratings tend to be highly correlated with borrowing costs. Cantor and Packer (1996) were among the first to focus on the relationship between default history and credit ratings. Collecting data for about 50 countries in 1995, they find that a dummy variable equal to one for countries that defaulted after 1970 is associated with a significant drop in a country's credit rating. Reinhart et al. (2003) find that a history of default is associated with lower ratings assigned by the Institutional Investor publication. ${ }^{28}$

\section{$5.1 \quad$ Data}

In this section my dependent variable is a country's (annual) sovereign rating provided by one of three rating agencies: Fitch, Moody's and Standard and Poor's. These ratings are overall available for only 70 of my initial sample of 117 countries, and only for the years $1990-2013 .^{29}$ In the analysis the ratings from these three agencies are pooled in order to increase the number of total observations. I then include a dummy for each agency to account for any systematic differences across them. For the empirical analysis, all ratings have been translated to a 21-point scale in accordance with the literature (e.g., see Borenstein and Panizza 2009 for a similar approach). This means that I assign the highest value of 20 for an "AAA" rating, 19 to AAp (or AA+), 18 to AA, and so forth,

\footnotetext{
${ }^{28}$ More recently, Fuchs and Gehring (2015) investigates how the home country of rating agencies could affect rating decisions as a result of political economy influences and cultural distance. Using data from nine agencies (based in six countries), they find that agencies have biases in favor of the respective home countries, as well as in favor of countries culturally more similar countries, and countries in which home-country banks have a larger risk exposure.

${ }^{29}$ More specifically, I focus on sovereign's long term foreign currency rating, i.e., ratings for government bonds that are issued in a foreign currency and have a maturity of more than one year. For each agency, and for each year, I took the latest in the year available credit rating.
} 
all the way down to selective default rating, SD, which is assigned a value of zero.

Alternatively, as in Reinhart et al. (2003), I take as dependent variable the Institutional Investor's crediworthiness index (Reinhart and Rogoff 2009). This index, however, further reduces our initial sample to only 39 countries and it is available for the period 1979-2008. ${ }^{30}$

The pair-wise correlation between sovereign ratings and the three credit rating agencies under analysis, and between the pooled credit rating by Fitch, Moody's and Standard and Poor's and the Institutional Investor's index, are all shown in Table A4.

\subsection{Method}

In this subsection, I analyze the relationship between private and official restructuring and credit rating over the 1990-2013 period. I obtain an unbalanced panel which comprises a maximum of 70 developing countries, depending on the control variables I include. I adopt a robust OLS fixed effects estimator in order to control for country unobservables and to correct for heteroskedasticity. ${ }^{31}$ Ordinary least squares treat the dependent variable as cardinal. This implies that the difference between an "AA" and an "AA+" rating, for example, is the same as between "BB" and "BB+." Nonetheless, I will also show, in the appendix, the results of an ordered probit model for the discrete 21-step rating at the end of each year. ${ }^{32}$

Specifically I test:

$$
c_{i t}=\alpha+\beta Z_{i t}+\gamma_{j} R_{i t+j}+\delta_{j} D_{i t+j}+\eta_{i}+\tau_{t}+\varepsilon_{i t}, \quad j=-1, \ldots+3,+4 \& 5,+6 \& 7
$$

where $c_{i t}$ represents credit rating (credit index) in country $i$ at period $t, R_{i t+j}$ is the amount restructured (private or official) associated to the default of the year $t$ in country $i, D_{i t+j}$ is an indicator variable equal to one when country $i$, in year $t$, has finalized its last restructuring, and $Z$ is a vector containing my control variables. Finally, $\eta_{i}$ and $\tau_{t}$ denote country and time dummies, respectively, which allow us to control for both countries unobservable and time invariant variation and common trends.

\footnotetext{
${ }^{30}$ Results ara available on request.

${ }^{31}$ I have tested for the normality of the pooled credit rating by Fitch, Moody's and Standard and Poor's and the hypothesis that it is normally distributed could not be rejected at conventional levels.

${ }^{32}$ I can report only the direction of the effect and the significance levels as marginal effects are conditional on each respective rating level.
} 
Since the number of observations is now much lower, following Cruces and Trebesch (2013a), I generated only seven variables denoting the anticipated restructuring dummy, current restructuring dummy and up to seven leads of each restructuring episode; and seven more variables denoting the haircut (and the official restructuring) at $t-1, t$ and up to seven years following the sovereign debt restructuring. As above, the advantage of estimating equation (2) is that it allows me to disentangle the "occurrence" versus "magnitude" effect of a (private and official) restructuring.

As the control variables are concerned I also rely on the specification by Cruces and Trebesch (2013a). ${ }^{33}$ As they do, to capture the sovereign's domestic economic performance, we included, public debt to GDP, the general government net lending/borrowing, per capita GDP, GDP real growth, total population (in log), reserves to imports, inflation rate (based on consumer prices), current account, the ICRG political risk indicator and the number of years the chief executive has been in office. ${ }^{34}$

Table A2 in the Appendix provides a detailed description of each control variable and its source while table A3 shows some summary statistics.

\subsection{Haircut}

The results of the model of equation (2) are presented in table 7. In columns 1-3, I report only the coefficients of the haircut dummy, the haircut and of both variables together, in the year of the restructuring, one year before and one year after the default episode. without including any control variables. Column 4 reports the same specification of column 3 including control variables. In columns 5-8, I progressively add the coefficients of both the haircut dummies and size (from up to three to up to six and seven years after the default) to the specification of column 4 . While all these results are reported for comparison, I largely base the discussion on the fully specified model of column $8 .{ }^{35}$

As can be seen, most of the control variables have the expected sign. Credit rating significantly increases with per capita GDP and with current account surplus, while it

\footnotetext{
${ }^{33}$ In their paper the dependent variable were bond yield spreads and periods of capital market exclusion.

${ }^{34}$ As the variable "general government net lending/borrowing" reduces substantially the sample size we present the results excluding it. The results, which are available on request, are qualitatively unchanged when we include this control.

${ }^{35}$ In table A5 I also report the results of the same specification when using ordered probit instead of OLS. The statistic for computing an ordered probit (or logit) model with fixed effects does not provide consistent estimates, thus in this case I cannot control for country time invariant unobservables.
} 
decreases with higher public debt and higher inflation. The coefficients of GDP real growth, population, reserves to imports, inflation, years in office and (absence of) political risk are not significant at conventional levels. Among the credit agencies, I observe a systematic downward bias for the ratings provided by Standard and Poor's.

If we look at the short-term link between credit rating and the haircut, we can detect a negative and significant, at the ten-percent level, coefficient of the haircut dummy one year after the restructuring. In turn, the amount which is restructured is significantly (at the five-percent level) associated with a decrease in the credit rating two years after the default. The quantitative effect of our variables of interest is remarkable, while the simple occurrence of a restructuring is associated with a drop of about 2.5 notches in a country's rating, an increase of one standard deviation in the haircut size is associated with a drop of about 0.6 notch in a country's rating. ${ }^{36}$

Over a longer period, the link between the occurrence of a private restructuring and the variation in the credit rating becomes eventually positive since four/five and up to seven years after the default episode. As the haircut size is concerned, its coefficient is still negative and significant since four/five and up to seven years after the default. ${ }^{37}$ After four/five years since the restructuring, while the simple occurrence of a private restructuring is associated with an increase 3.8 notches in a country's credit, an increase of one standard deviation in the haircut size is associated with a drop of about 0.9 notch in a country's credit.

Similarly to the results of Table 2, correlation between private restructuring and credit rating remains negative up to one year after the default episode and eventually turns out to be positive, while the haircut size involves some reputational costs. These results are similar to those of Cruces and Trebesch (2013a). As they do, by controlling for both the occurrence and the magnitude of private default I am able to detect a more lasting (and negative) link between debt default and borrowing costs. However, differently from them, the haircut's size and the haircut dummy have always the opposite sign.

In sum, my results confirm that at least one of the channels leading to a growth recovery after a default may due to an improvement in the credit market as the perception of private investors is improving in a few years after a restructuring episode. Nevertheless,

\footnotetext{
${ }^{36} \mathrm{~A}$ rating notch is a one-level difference on a rating scale, such as the difference between A1 and A2 for Moody's or between A+ and A for Standard and Poor's (Cantor and Packer 1996).

${ }^{37}$ The coefficient of the haircut dummy (and haircut size) after six and seven years after the default are still positive (negative) but not significant at conventional level, p-value 0.17 (p-value 0.15).
} 
the characteristics of the deal (the size of the haircut) seem to be persistent: higher haircuts are still associated to higher ratings up to five years after the default. I should emphasize, though, that the comparison between the two sets of results should be taken cautiously as the sample size and year period do not coincide.

\subsection{Official Restructuring}

The results for official restructurings are presented in table 8. In columns 1-3, I report only the coefficients of the official restructuring dummy, the amount of official restructuring and of both variables together, in the year of the restructuring, one year before and one year after the default episode without any control variables. Column 4 reports the same specification of column 3 including control variables. In columns 5-8, I progressively add the coefficients of both the official restructuring dummies and size (from up to three to up to six and seven years after the default) to the specification of column 4 . As before, I largely base the discussion on the fully specified model of column $8 .{ }^{38}$

As can be seen, as above, most of the control variables have the expected sign. Credit rating significantly increases with per capita GDP, with current account surplus and with absence of political risk, while it decreases with higher public debt and GDP real growth. The coefficients of population, reserves to imports, inflation and years in office are not significant at conventional levels. I do not observe anymore any systematic differences among the credit agencies' evaluations.

Looking at the short-term link between credit rating and official restructuring, we can observe that the occurrence of an official restructuring is associated to a drop in the credit rating in the same year and one year after the default episode, which is however mitigated by the restructuring size. Specifically, one year after the official restructuring, while the simple occurrence of a restructuring is highly significant, the amount of official restructuring positively correlates with credit rating. Regarding the quantitative impact of my variables of interest, the occurrence of a restructuring is associated with a drop of about two notches in a country's credit, while an increase of one standard deviation in the amount of official restructuring is associated with an increase of about one notch in a country's credit.

\footnotetext{
${ }^{38} \mathrm{As}$ it is shown in table A6, the results are qualitatively unchanged when using ordered probit instead of OLS.
} 
Looking to a longer period, we observe that the evidence of a correlation between official restructuring and credit rating becomes blurred. In particular, both the occurrence and the magnitude of an official restructuring are hardly significant, with the only exception of the amount of an official restructuring made in the third year after the default, which is negative and significant at the one-percent level. ${ }^{39}$ In sum, the correlation between credit rating and official restructuring seems to be significant only in the short term, while over the longer period the evidence is more mixed and default costs seem to be less persistent.

\section{Conclusions}

This paper studies the relationship between debt default and GDP growth, over a period of ten years, by taking into account the depth of a debt restructuring and by distinguishing between commercial and official sovereign debt restructuring. More specifically, the amount of restructured debt is used as a proxy of the severity of the default episode. Analyzing default episodes in 117 countries over the period 1975-2013, consistently with previous results in this literature, I find that defaults are correlated with significant contraction of short-term output growth.

Moreover, controlling for the severity of the default, I find that a (commercial debt) default is indeed correlated with a further contraction in output up to five years after the default (which is however softened by the size of the haircut) but also with an increase in economic growth ten years after the default (which is however reduced by the haircut size). For official debt restructuring, evidence of correlation between growth and official restructuring is actually weaker in the short run, but there is now evidence of a negative correlation between growth and the official restructuring dummy seven years after the default.

More generally, by controlling for both the occurrence and the magnitude of both private and official defaults, I am able to detect a more lasting and negative link between debt default and growth, which eventually turns out to be positive (but only for haircuts). In both cases, occurrence and magnitude goes into opposite direction and in both cases I find evidence of a trade-off concerning the amount of a sovereign debt restructuring. However, while high haircuts have some benefits in the short-run, but seem to imply a negative stigma lowering growth over a longer period. Alternatively, higher amount

\footnotetext{
${ }^{39}$ In particular, an increase of one standard deviation in the amount of official restructuring is associated with a decrease of about 0.8 notch in a country's credit.
} 
of official restructuring may have some costs in the short-run, but they do have some positive effects over the long run, as the debt relief effect of high restructurings seems to improve recovery. In this case, no stigma is associated to the size of the restructuring, indeed defaulters seem to benefit from the debt relief effect of high restructurings (as in Arslanalp and Henry, 2005), which somehow soften the negative consequences of an official default.

Thus, while more severe haircuts seem, at the same time, more beneficial in terms of growth in the short-term but also more costly in the medium-term, the opposite holds for official restructuring. In other words, there should exist an optimal size of the restructuring balancing the ex-ante efficiency of a debt restructuring with its efficiency ex-post. Deriving implications concerning the optimal size of the haircut, however, is not so obvious. For example, lowering too much the costs of renegotiations could make a default too easy by increasing the spread requested ex ante by the investors (as shown by Cruces and Trebesch 2013a).

Adopting an alternative specification, in which the dependent variable is a country's credit rating, I investigate whether one of the channels explaining the link between restructuring and growth may depend on the borrowing conditions (which highly correlate with credit ratings). As above, I find different results in the case of private and official restructuring. In the case of haircuts, my results confirms that one of the channels leading to a growth recovery after a default may be due to an improvement in the borrowing conditions. The perception of private investors does seem to improve a few years after the restructuring episode, even if this effect is mitigated by the size of the haircuts.

For official restructurings the evidence is blurred. In particular, credit rating and official restructuring seem to be correlated only in the short term and default costs seem less persistent over a longer period. If defaulting on private or official debt is not the same, this distinction could be, for example, especially instructive in the case of Greece, where private debt has been replaced by official debt.

The analysis is of course limited in several respects. I do not claim to draw causal inferences from the empirical analysis, given the nature of the data available. I do emphasize that the direction of causality in the relationship between sovereign defaults and growth raises some questions and thus a robust association between debt defaults and low growth can only be indicative of a correlation between the two variables. Lower growth might not be the consequence of a default per se but of other factors affecting debt sustainability as 
well. Thus, both the determinants and the effects of a debt restructuring should be more carefully investigated.

I also plan to check the robustness of the results by exploring the differences between different degrees of "concessionality" in the new debt contract (in particular quantifying the relief achieved through default and restructuring (see Trebesch and Reinarth 2015).

\section{References}

[1] Arslanalp S., P.B. Henry. 2005. Is debt relief efficient? Journal of finance, 62: 2, pp. 1017-051.

[2] Asonuma and Trebesch. 2015. Sovereign Debt Restructurings: Pre-emptive or PostDefault," forthcoming in the Journal of the European Economic Association.

[3] Beers D.T. and J. Chambers. 2007. Default Study: Sovereign Defaults At 26-Year Low, To Show Little Change In 2007. Standard and Poor's, Global Credit Portal www.standardandpoors.com/ratingsdirect

[4] Benjamin, D. and M.L. Wright. 2009. Recovery Before Redemption: a Theory of Delays in Sovereign Debt Renegotiations. CAMA Working Paper Series.

[5] Borensztein E. and U. Panizza. 2009. The costs of sovereign default. IMF Staff Papers $56(4), 683-741$

[6] Borensztein E., and U. Panizza. 2010. Do Sovereign Defaults Hurt Exporters? Open Economic Review 21(3), 339-412.

[7] Bulow, J. and K.S. Rogoff. 1989a. A Constant Recontracting Model of Sovereign Debt. Journal of Political Economy, 97(1): 155-78.

[8] Bulow J. and K. Rogoff. 1989b. Sovereign Debt: Is to Forgive to Forget? American Economic Review 79(1), 43-50.

[9] Cantor R. and F. Packer. 1996. Determinants and Impact of Sovereign Credit Ratings. Economic Policy Review, Federal Reserve Bank of New York 2(2), 37-53.

[10] Cline, William, 1995. International Debt Reexamined. Washington, DC: Institute for International Economics 
[11] Cole H.L., Dow J. and W.B. English. 1995. Default, Settlement and Signalling: Lending Resumption in a Reputational Model of Sovereign Debt. International Economic Review, 36, 365-384.

[12] Cruces J. J. and C. Trebesch. 2013a. Sovereign Defaults: The Price of Haircuts. American Economic Journal: Macroeconomics 5, 85-117

[13] Cruces J. J. and C. Trebesch. 2013b. Sovereign Defaults: The Price of Haircuts: Dataset. American Economic Journal: Macroeconomics. http://dx.doi.org/10.1257/mac.5.3.85.

[14] Das, Papaioannou and Trebesch. 2011. Sovereign Debt Restructurings 1950-2010: Literature Survey, Data and Stylized Facts. IMF Working Paper 12/203

[15] Trebesch C. and M. Zabely. 2014. The Output Costs of Hard and Soft Sovereign Default. Mimeo

[16] De Paoli B., Hoggarth G., and V. Saporta. 2006. Costs of Sovereign Default. Financial Stability Paper No. 1.

[17] De Paoli B., Hoggarth G. and V. Saporta. 2009. Output costs of sovereign crises: some empirical estimates. Bank of England Working Paper No. 362.

[18] Eaton J J. and M. Gersovitz. 1981. Debt with Potential Repudation: Theoretical and Empirical Analysis. Review of Economic Studies 48(2), 289-309.

[19] English W.B. 1996. Understanding the Costs of Sovereign Default: American State Debts in the 1840's. American Economic Review 86 (1), pp. 259-275.

[20] Fitch - Complete Sovereign Rating History. 2012. https://www.fitchratings.com

[21] Freedom House. 2015. Freedom of the Press Index

[22] Fuchs A. and K. Gehring. 2015. The Home Bias in Sovereign Ratings. Courant Research Centre Discussion Paper

[23] Furceri F. and A. Zdzienicka 2012. How costly are debt crises? Journal of International Money and Finance 31, 726-742

[24] Gelos G., Sahay R. and G. Sandleris. 2011. Sovereign Borrowing by developing countries: what determines market Access? Journal of International Economics 83 (2), $243-254$. 
[25] International Country Risk Guide. 2013. Country Rankings, The PRS Group, Various Years

[26] International Monetary Fund. 2013. World Economic Outlook Database. Washington, $\mathrm{DC}$

[27] International Monetary Fund. 2015. International Financial Statistics. Washington, $\mathrm{DC}$

[28] Krugman P. 1988. Financing vs. forgiving a debt overhang. Journal of Development Economics 29(3): 253-268.

[29] Judson, R.A., Owen, A.L., 1999. Estimating dynamic panel data models: a guide for macroeconomists. Economic Letters, 65, 9-15.

[30] Loeven L. and F. Valentia. 2013. Systemic Banking Crises Database: An Update. IMF Economic Review, 61 (2), 225-270.

[31] Levy Yeyati E. and U. Panizza. 2011. The Elusive Costs of Sovereign Defaults. Journal of Development Economics 94, 95-105.

[32] Mendoza, E. G. and V. Z. Yue. 2012. A General Equilibrium Model of Sovereign Default and Business Cycles. The Quarterly Journal of Economics, 127: 889-946.

[33] Moody's Investor Service. 2013 Sovereign Rating History. 2013. https://www.moodys.com

[34] Nickell, S.J., 1981. Biases in dynamic models with fixed effects. Econometrica, 49, 802-816.

[35] Ozler S. 1993. Have commercial banks ignored history? American Economic Review 89 (3), 473-500.

[36] Panizza U., Sturzenegger F. and J. Zettelmeyer. 2009. The Economics and Law of Sovereign Debt and Default. Journal of Economic Literature 47(3), 1-47.

[37] Reinhart, C.M., K. S. Rogoff, and M. A. Savastano.2003. Debt Intolerance. Brookings Papers on Economic Activity: 1, Brookings Institution

[38] Reinhart C. M. and K.S. Rogoff. 2009. This Time is Different: Eight Centuries of Financial Follies. Princeton University Press. 
[39] Reinhart, C. M. and C. Trebesch. 2015. Sovereign Debt Relief and its Aftermath. Forthcoming in the Journal of the European Economic Association.

[40] Rose A. K. 2005. One Reason Countries Pay Their Debts: Renegotiation and International Trade. Journal of Development Economics 77, 189-206.

[41] Sandleris, G. (2008) Sovereign Defaults: Information, Investment and Credit. Journal of International Economics 76: 267- 275.

[42] Sturzenegger F. 2004. Tools for the Anlysis of debt problems. Journal of Reconstructing Finance 1(1), 1 - 23.

[43] Sturzenegger F. and J. Zettelmeyer. 2008. Haircuts: Estimating Investor Losses in Sovereign Debt Restructurings, 1998-2005. Journal of International Money and Finance 27, 780-805.

[44] Tomz M. and M. Wright. 2007. Do countries default in bad times? Journal of the European Economic Association 5 (2), 352-360.

[45] Tomz M. and M. L. J. Wright. 2013 Empirical Research On Sovereign Debt And Default. NBER Working Paper 18855

[46] World Bank. 2012. Database of Political Institutions. Washington, DC

[47] World Bank. 2015. World Development Indicators. Washington, DC

[48] Zettelmeyer J., Trebesch C. and M. Gulati. 2013. The Greek Debt Restructuring: An Autopsy. CESifo Working Paper No. 4333 
Table 1: Haircut and Official Restructuring over time

\begin{tabular}{lccccc}
\hline \hline & Observations & Mean & SD & Min & Max \\
\hline Haircut & & & & & \\
$1975-1988$ & 79 & 27.75 & 18.92 & 0.7 & 103.5 \\
$1989-2001$ & 43 & 53.5 & 29.66 & 8.7 & 102.3 \\
$2002-2013$ & 11 & 66.37 & 33.34 & 5.63 & 97 \\
& & & & & \\
Official restructuring & & & & & \\
1975-1988 & 121 & 6.86 & 6.17 & 0.4 & 30.33 \\
$1989-2001$ & 139 & 10.4 & 12.72 & 0.03 & 82.06 \\
$2002-2013$ & 41 & 31.38 & 55.27 & 0.43 & 326.13 \\
\hline \hline
\end{tabular}

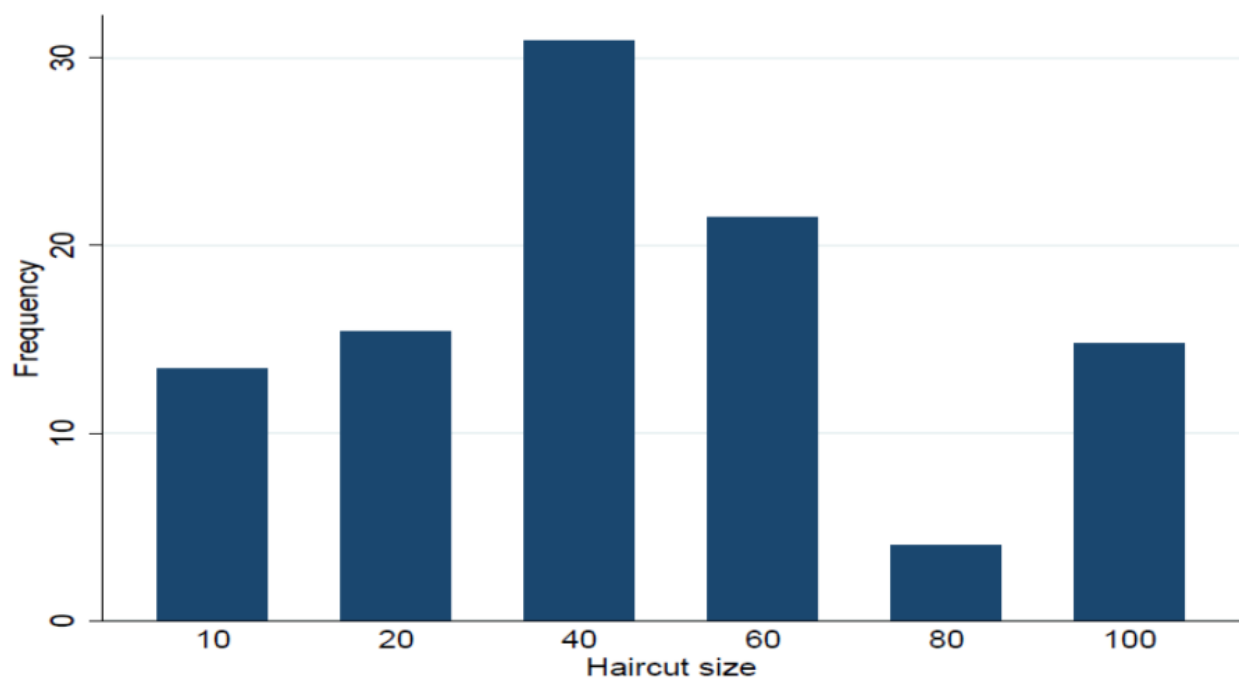

Figure 1: Haircuts frequency by size (percent)

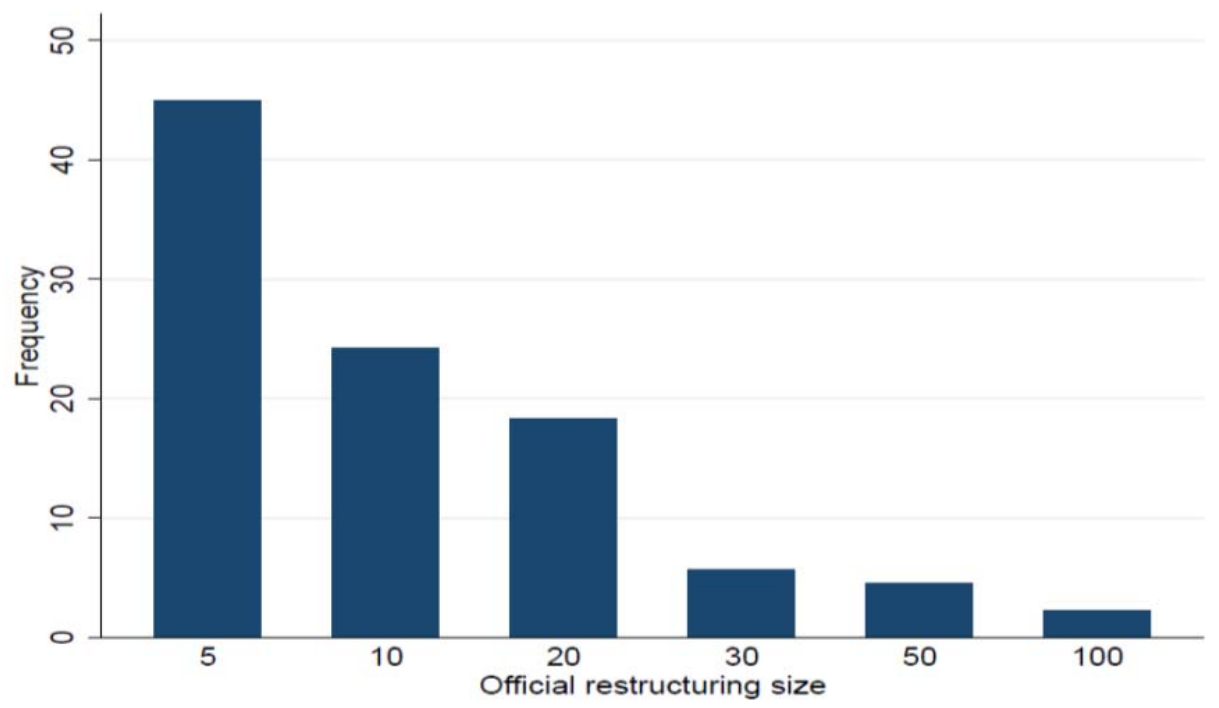

Figure 2: Official restructurings frequency by size (percent) 
Table 2: Haircuts and Growth, 1975-2013, OLS

\begin{tabular}{|c|c|c|c|c|c|c|c|c|}
\hline & $(1)$ & (2) & (3) & $(4)$ & (5) & (6) & (7) & $(8)$ \\
\hline Haircut dummy (-1) & $\begin{array}{c}1.402^{* * *} \\
(4.052)\end{array}$ & & $\begin{array}{c}2.001^{* * *} \\
(3.040)\end{array}$ & $\begin{array}{c}2.710^{* * *} \\
(2.941)\end{array}$ & $\begin{array}{c}3.028^{* * *} \\
(3.124)\end{array}$ & $\begin{array}{c}3.010^{* * *} \\
(3.128)\end{array}$ & $\begin{array}{c}3.016^{* * *} \\
(3.005)\end{array}$ & $\begin{array}{c}3.520^{* * *} \\
(3.224)\end{array}$ \\
\hline Haircut dummy & $\begin{array}{c}0.633 \\
(1.408)\end{array}$ & & $\begin{array}{c}-0.689 \\
(-0.892)\end{array}$ & $\begin{array}{c}0.652 \\
(0.634)\end{array}$ & $\begin{array}{c}0.849 \\
(0.827)\end{array}$ & $\begin{array}{c}1.075 \\
(1.123)\end{array}$ & $\begin{array}{c}0.913 \\
(0.939)\end{array}$ & $\begin{array}{c}0.928 \\
(0.945)\end{array}$ \\
\hline Haircut dummy $(+1)$ & $\begin{array}{c}-0.042 \\
(-0.094)\end{array}$ & & $\begin{array}{c}-2.478^{* * *} \\
(-3.588)\end{array}$ & $\begin{array}{l}-2.254^{* *} \\
(-2.433)\end{array}$ & $\begin{array}{l}-2.105^{* *} \\
(-2.438)\end{array}$ & $\begin{array}{l}-1.856^{* *} \\
(-2.345)\end{array}$ & $\begin{array}{c}-1.989^{* * *} \\
(-2.660)\end{array}$ & $\begin{array}{l}-1.982^{* *} \\
(-2.329)\end{array}$ \\
\hline Haircut dummy (+2) & & & & & $\begin{array}{c}-0.473 \\
(-0.401)\end{array}$ & $\begin{array}{c}-0.053 \\
(-0.046)\end{array}$ & $\begin{array}{c}-0.189 \\
(-0.170)\end{array}$ & $\begin{array}{c}0.138 \\
(0.124)\end{array}$ \\
\hline Haircut dummy $(+3)$ & & & & & $\begin{array}{c}-0.815 \\
(-0.686)\end{array}$ & $\begin{array}{c}-0.429 \\
(-0.384)\end{array}$ & $\begin{array}{c}-0.491 \\
(-0.438)\end{array}$ & $\begin{array}{c}-0.628 \\
(-0.515)\end{array}$ \\
\hline Haircut dummy $(+4)$ & & & & & & $\begin{array}{c}-0.803 \\
(-0.612)\end{array}$ & $\begin{array}{c}-0.599 \\
(-0.454)\end{array}$ & $\begin{array}{c}-0.306 \\
(-0.227)\end{array}$ \\
\hline Haircut dummy $(+5)$ & & & & & & $\begin{array}{l}-1.839^{*} \\
(-1.705)\end{array}$ & $\begin{array}{l}-1.767^{*} \\
(-1.705)\end{array}$ & $\begin{array}{c}-1.539 \\
(-1.411)\end{array}$ \\
\hline Haircut dummy $(+6)$ & & & & & & & $\begin{array}{c}-0.591 \\
(-0.408)\end{array}$ & $\begin{array}{c}-0.282 \\
(-0.201)\end{array}$ \\
\hline Haircut dummy $(+7)$ & & & & & & & $\begin{array}{c}-0.619 \\
(-0.588)\end{array}$ & $\begin{array}{c}-0.462 \\
(-0.459)\end{array}$ \\
\hline Haircut dummy $(+8)$ & & & & & & & & $\begin{array}{c}0.110 \\
(0.096)\end{array}$ \\
\hline Haircut dummy (+9) & & & & & & & & $\begin{array}{c}-0.262 \\
(-0.265)\end{array}$ \\
\hline Haircut dummy $(+10)$ & & & & & & & & $\begin{array}{l}1.751^{* *} \\
(2.137)\end{array}$ \\
\hline Haircut (-1) & & $\begin{array}{c}0.020^{* * *} \\
(2.625)\end{array}$ & $\begin{array}{c}-0.012 \\
(-0.870)\end{array}$ & $\begin{array}{l}-0.036^{* *} \\
(-2.054)\end{array}$ & $\begin{array}{l}-0.043^{* *} \\
(-2.357)\end{array}$ & $\begin{array}{l}-0.043^{* *} \\
(-2.307)\end{array}$ & $\begin{array}{l}-0.050^{* *} \\
(-2.206)\end{array}$ & $\begin{array}{l}-0.060^{* *} \\
(-2.465)\end{array}$ \\
\hline Haircut & & $\begin{array}{l}0.022^{* *} \\
(2.288)\end{array}$ & $\begin{array}{l}0.033^{*} \\
(1.950)\end{array}$ & $\begin{array}{c}0.017 \\
(0.785)\end{array}$ & $\begin{array}{c}0.013 \\
(0.567)\end{array}$ & $\begin{array}{c}0.006 \\
(0.268)\end{array}$ & $\begin{array}{c}0.006 \\
(0.265)\end{array}$ & $\begin{array}{c}0.004 \\
(0.171)\end{array}$ \\
\hline Haircut $(+1)$ & & $\begin{array}{c}0.021^{* * *} \\
(2.788)\end{array}$ & $\begin{array}{c}0.061^{* * *} \\
(4.847)\end{array}$ & $\begin{array}{l}0.043^{* *} \\
(2.119)\end{array}$ & $\begin{array}{c}0.040^{*} \\
(1.985)\end{array}$ & $\begin{array}{c}0.034^{*} \\
(1.923)\end{array}$ & $\begin{array}{l}0.035^{* *} \\
(2.123)\end{array}$ & $\begin{array}{c}0.039^{*} \\
(1.779)\end{array}$ \\
\hline Haircut (+2) & & & & & $\begin{array}{c}-0.015 \\
(-0.667)\end{array}$ & $\begin{array}{c}-0.024 \\
(-1.005)\end{array}$ & $\begin{array}{c}-0.022 \\
(-0.935)\end{array}$ & $\begin{array}{c}-0.032 \\
(-1.214)\end{array}$ \\
\hline Haircut $(+3)$ & & & & & $\begin{array}{c}0.006 \\
(0.211)\end{array}$ & $\begin{array}{c}-0.001 \\
(-0.042)\end{array}$ & $\begin{array}{c}-0.001 \\
(-0.048)\end{array}$ & $\begin{array}{c}0.007 \\
(0.209)\end{array}$ \\
\hline Haircut $(+4)$ & & & & & & $\begin{array}{c}0.009 \\
(0.362)\end{array}$ & $\begin{array}{c}0.006 \\
(0.234)\end{array}$ & $\begin{array}{c}0.002 \\
(0.094)\end{array}$ \\
\hline Haircut $(+5)$ & & & & & & $\begin{array}{c}0.010 \\
(0.579)\end{array}$ & $\begin{array}{c}0.009 \\
(0.513)\end{array}$ & $\begin{array}{c}0.005 \\
(0.243)\end{array}$ \\
\hline Haircut $(+6)$ & & & & & & & $\begin{array}{c}0.008 \\
(0.341)\end{array}$ & $\begin{array}{c}0.004 \\
(0.167)\end{array}$ \\
\hline Haircut $(+7)$ & & & & & & & $\begin{array}{c}-0.007 \\
(-0.353)\end{array}$ & $\begin{array}{c}-0.009 \\
(-0.425)\end{array}$ \\
\hline Haircut $(+8)$ & & & & & & & & $\begin{array}{c}-0.009 \\
(-0.393)\end{array}$ \\
\hline Haircut (+9) & & & & & & & & $\begin{array}{c}0.001 \\
(0.059)\end{array}$ \\
\hline Haircut $(+10)$ & & & & & & & & $-0.037^{*}$ \\
\hline
\end{tabular}




\begin{tabular}{|c|c|c|c|c|c|c|c|c|}
\hline Investment & & & & $\begin{array}{c}0.205^{* * *} \\
(5.748)\end{array}$ & $\begin{array}{c}0.201^{* * *} \\
(5.769)\end{array}$ & $\begin{array}{c}0.193^{* * * *} \\
(4.989)\end{array}$ & $\begin{array}{c}0.202^{* * *} \\
(4.782)\end{array}$ & $\begin{array}{c}0.217^{* * *} \\
(4.615)\end{array}$ \\
\hline (delta) Population & & & & $\begin{array}{c}-0.116 \\
(-0.323)\end{array}$ & $\begin{array}{c}-0.087 \\
(-0.237)\end{array}$ & $\begin{array}{c}-0.017 \\
(-0.045)\end{array}$ & $\begin{array}{c}0.052 \\
(0.127)\end{array}$ & $\begin{array}{c}-0.143 \\
(-0.332)\end{array}$ \\
\hline Secondary Edu & & & & $\begin{array}{l}-0.071^{* *} \\
(-2.337)\end{array}$ & $\begin{array}{l}-0.068^{* *} \\
(-2.166)\end{array}$ & $\begin{array}{l}-0.087^{* *} \\
(-2.387)\end{array}$ & $\begin{array}{l}-0.078^{* *} \\
(-1.997)\end{array}$ & $\begin{array}{l}-0.082^{*} \\
(-1.777)\end{array}$ \\
\hline (log) Popolation & & & & $\begin{array}{l}-5.686^{* *} \\
(-2.509)\end{array}$ & $\begin{array}{l}-5.802^{* *} \\
(-2.448)\end{array}$ & $\begin{array}{c}-8.921^{* * *} \\
(-3.251)\end{array}$ & $\begin{array}{c}-9.859^{* * *} \\
(-3.078)\end{array}$ & $\begin{array}{c}-11.401^{* * *} \\
(-2.721)\end{array}$ \\
\hline Government Cons. & & & & $\begin{array}{c}-0.202^{* * *} \\
(-4.164)\end{array}$ & $\begin{array}{c}-0.221^{* * *} \\
(-4.418)\end{array}$ & $\begin{array}{c}-0.246^{* * *} \\
(-4.596)\end{array}$ & $\begin{array}{c}-0.250^{* * *} \\
(-4.273)\end{array}$ & $\begin{array}{c}-0.231^{* * * *} \\
(-3.759)\end{array}$ \\
\hline Civil Liberties & & & & $\begin{array}{l}0.470^{* *} \\
(2.118)\end{array}$ & $\begin{array}{l}0.479^{* *} \\
(2.112)\end{array}$ & $\begin{array}{l}0.570^{* *} \\
(2.389)\end{array}$ & $\begin{array}{l}0.520^{* *} \\
(2.111)\end{array}$ & $\begin{array}{c}0.381 \\
(1.417)\end{array}$ \\
\hline (delta) Terms of Trade & & & & $\begin{array}{c}0.317^{* * *} \\
(4.596)\end{array}$ & $\begin{array}{c}0.322^{* * *} \\
(4.378)\end{array}$ & $\begin{array}{c}0.334^{* * *} \\
(5.011)\end{array}$ & $\begin{array}{c}0.338^{* * * *} \\
(4.959)\end{array}$ & $\begin{array}{c}0.323^{* * *} \\
(5.335)\end{array}$ \\
\hline Openness & & & & $\begin{array}{c}-0.014 \\
(-0.985)\end{array}$ & $\begin{array}{c}-0.014 \\
(-0.950)\end{array}$ & $\begin{array}{c}-0.018 \\
(-1.159)\end{array}$ & $\begin{array}{c}-0.021 \\
(-1.206)\end{array}$ & $\begin{array}{c}-0.022 \\
(-1.156)\end{array}$ \\
\hline Banking Crises & & & & $\begin{array}{c}-1.472^{* * *} \\
(-2.757)\end{array}$ & $\begin{array}{l}-1.345^{* *} \\
(-2.397)\end{array}$ & $\begin{array}{l}-1.393^{* *} \\
(-2.450)\end{array}$ & $\begin{array}{l}-1.174^{*} \\
(-1.963)\end{array}$ & $\begin{array}{l}-1.255^{* *} \\
(-2.049)\end{array}$ \\
\hline Constant & $\begin{array}{c}0.531 \\
(0.677)\end{array}$ & $\begin{array}{c}0.528 \\
(0.675)\end{array}$ & $\begin{array}{c}0.573 \\
(0.733)\end{array}$ & $\begin{array}{c}102.190^{* *} \\
(2.633)\end{array}$ & $\begin{array}{c}104.346^{* *} \\
(2.577)\end{array}$ & $\begin{array}{c}157.887^{* * * *} \\
(3.371)\end{array}$ & $\begin{array}{c}175.400^{* * * *} \\
(3.210)\end{array}$ & $\begin{array}{c}195.514^{* * *} \\
(2.768)\end{array}$ \\
\hline Observations & 3,828 & 3,828 & 3,828 & 1,485 & 1,434 & 1,332 & 1,233 & 1,087 \\
\hline Country FE & YES & YES & YES & YES & YES & YES & YES & YES \\
\hline Time FE & YES & YES & YES & YES & YES & YES & YES & YES \\
\hline R-squared & 0.079 & 0.079 & 0.082 & 0.242 & 0.242 & 0.247 & 0.230 & 0.189 \\
\hline Number of id & 117 & 117 & 117 & 73 & 72 & 70 & 68 & 67 \\
\hline
\end{tabular}

Robust t-statistics in parentheses ${ }^{* * *} \mathrm{p}<0.01,{ }^{* *} \mathrm{p}<0.05,{ }^{*} \mathrm{p}<0.1$ 
Table 3: Official Restructurings and Growth, 1975-2013, OLS

\begin{tabular}{|c|c|c|c|c|c|c|c|c|}
\hline & $\overline{(\overline{(1)}}$ & $\overline{(2)}$ & 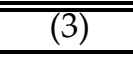 & 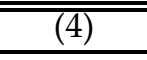 & 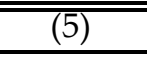 & 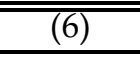 & $\overline{(7)}$ & $\overline{(8)}$ \\
\hline Off. Restr. dummy (-1) & $\begin{array}{c}1.010^{* * *} \\
(3.317)\end{array}$ & & $\begin{array}{c}0.694^{*} \\
(1.967)\end{array}$ & $\begin{array}{c}0.566 \\
(1.188)\end{array}$ & $\begin{array}{c}0.623 \\
(1.294)\end{array}$ & $\begin{array}{c}0.710 \\
(1.296)\end{array}$ & $\begin{array}{c}0.706 \\
(1.319)\end{array}$ & $\begin{array}{c}0.649 \\
(1.013)\end{array}$ \\
\hline Off. Restr. dummy & $\begin{array}{c}0.114 \\
(0.340)\end{array}$ & & $\begin{array}{c}0.273 \\
(0.770)\end{array}$ & $\begin{array}{c}0.687 \\
(1.154)\end{array}$ & $\begin{array}{c}0.648 \\
(1.071)\end{array}$ & $\begin{array}{c}0.564 \\
(0.905)\end{array}$ & $\begin{array}{c}0.772 \\
(1.111)\end{array}$ & $\begin{array}{c}1.026 \\
(1.476)\end{array}$ \\
\hline Off. Restr. dummy $(+1)$ & $\begin{array}{c}-0.215 \\
(-0.530)\end{array}$ & & $\begin{array}{l}-0.709^{*} \\
(-1.815)\end{array}$ & $\begin{array}{c}-0.933 \\
(-1.502)\end{array}$ & $\begin{array}{c}-1.039 \\
(-1.625)\end{array}$ & $\begin{array}{l}-1.084^{*} \\
(-1.761)\end{array}$ & $\begin{array}{c}-0.196 \\
(-0.329)\end{array}$ & $\begin{array}{c}-0.225 \\
(-0.369)\end{array}$ \\
\hline Off. Restr. dummy (+2) & & & & & $\begin{array}{c}-0.666 \\
(-1.043)\end{array}$ & $\begin{array}{c}-0.694 \\
(-1.116)\end{array}$ & $\begin{array}{c}-0.797 \\
(-1.224)\end{array}$ & $\begin{array}{c}-0.704 \\
(-0.933)\end{array}$ \\
\hline Off. Restr. dummy (+3) & & & & & $\begin{array}{c}-0.191 \\
(-0.369)\end{array}$ & $\begin{array}{l}-0.339 \\
(-0.642)\end{array}$ & $\begin{array}{c}-0.549 \\
(-1.027)\end{array}$ & $\begin{array}{l}-0.540 \\
(-0.998)\end{array}$ \\
\hline Off. Restr. dummy $(+4)$ & & & & & & $\begin{array}{c}-0.119 \\
(-0.207)\end{array}$ & $\begin{array}{c}-0.047 \\
(-0.085)\end{array}$ & $\begin{array}{c}0.325 \\
(0.615)\end{array}$ \\
\hline Off. Restr. dummy $(+5)$ & & & & & & $\begin{array}{c}0.221 \\
(0.415)\end{array}$ & $\begin{array}{c}0.176 \\
(0.318)\end{array}$ & $\begin{array}{c}0.266 \\
(0.458)\end{array}$ \\
\hline Off. Restr. dummy (+6) & & & & & & & $\begin{array}{c}0.165 \\
(0.330)\end{array}$ & $\begin{array}{c}0.191 \\
(0.358)\end{array}$ \\
\hline Off. Restr. dummy $(+7)$ & & & & & & & $\begin{array}{l}-1.280^{* *} \\
(-2.203)\end{array}$ & $\begin{array}{l}-1.437^{* *} \\
(-2.325)\end{array}$ \\
\hline Off. Restr. dummy $(+8)$ & & & & & & & & $\begin{array}{c}-0.521 \\
(-0.694)\end{array}$ \\
\hline Off. Restr. dummy (+9) & & & & & & & & $\begin{array}{l}-0.076 \\
(-0.123)\end{array}$ \\
\hline Off. Restr. dummy $(+10)$ & & & & & & & & $\begin{array}{c}-0.668 \\
(-1.086)\end{array}$ \\
\hline Official Restr (-1) & & $\begin{array}{l}0.048^{* *} \\
(2.532)\end{array}$ & $\begin{array}{c}0.027 \\
(1.524)\end{array}$ & $\begin{array}{c}-0.009 \\
(-0.607)\end{array}$ & $\begin{array}{c}-0.003 \\
(-0.211)\end{array}$ & $\begin{array}{c}-0.015 \\
(-0.601)\end{array}$ & $\begin{array}{c}-0.010 \\
(-0.375)\end{array}$ & $\begin{array}{c}-0.042 \\
(-0.911)\end{array}$ \\
\hline Official Restr & & $\begin{array}{c}0.001 \\
(0.047)\end{array}$ & $\begin{array}{l}-0.008 \\
(-0.517)\end{array}$ & $\begin{array}{c}-0.035 \\
(-1.563)\end{array}$ & $\begin{array}{c}-0.030 \\
(-1.147)\end{array}$ & $\begin{array}{l}-0.027 \\
(-0.990)\end{array}$ & $\begin{array}{l}-0.045 \\
(-0.839)\end{array}$ & $\begin{array}{l}-0.094^{*} \\
(-1.926)\end{array}$ \\
\hline Official Restr $(+1)$ & & $\begin{array}{l}0.035^{*} \\
(1.930)\end{array}$ & $\begin{array}{l}0.045^{* *} \\
(2.469)\end{array}$ & $\begin{array}{c}0.076 \\
(1.429)\end{array}$ & $\begin{array}{c}0.081 \\
(1.339)\end{array}$ & $\begin{array}{c}0.087 \\
(1.350)\end{array}$ & $\begin{array}{c}-0.022 \\
(-0.461)\end{array}$ & $\begin{array}{c}-0.018 \\
(-0.441)\end{array}$ \\
\hline Official Restr $(+2)$ & & & & & $\begin{array}{c}-0.006 \\
(-0.228)\end{array}$ & $\begin{array}{c}-0.009 \\
(-0.283)\end{array}$ & $\begin{array}{c}-0.011 \\
(-0.284)\end{array}$ & $\begin{array}{c}-0.034 \\
(-0.673)\end{array}$ \\
\hline Official Restr (+3) & & & & & $\begin{array}{c}0.001 \\
(0.066)\end{array}$ & $\begin{array}{c}-0.004 \\
(-0.218)\end{array}$ & $\begin{array}{c}0.004 \\
(0.246)\end{array}$ & $\begin{array}{c}-0.006 \\
(-0.136)\end{array}$ \\
\hline Official Restr $(+4)$ & & & & & & $\begin{array}{c}-0.013 \\
(-0.338)\end{array}$ & $\begin{array}{c}-0.003 \\
(-0.099)\end{array}$ & $\begin{array}{c}-0.045 \\
(-1.313)\end{array}$ \\
\hline Official Restr $(+5)$ & & & & & & $\begin{array}{c}0.002 \\
(0.089)\end{array}$ & $\begin{array}{c}0.012 \\
(0.351)\end{array}$ & $\begin{array}{c}0.034 \\
(0.881)\end{array}$ \\
\hline Official Restr (+6) & & & & & & & $\begin{array}{l}-0.006 \\
(-0.208)\end{array}$ & $\begin{array}{c}0.023 \\
(0.973)\end{array}$ \\
\hline Official Restr (+7) & & & & & & & $\begin{array}{c}0.034 \\
(1.110)\end{array}$ & $\begin{array}{l}0.065^{* *} \\
(2.092)\end{array}$ \\
\hline Official Restr $(+8)$ & & & & & & & & $\begin{array}{c}0.007 \\
(0.178)\end{array}$ \\
\hline Official Restr (+9) & & & & & & & & $\begin{array}{c}0.006 \\
(0.149)\end{array}$ \\
\hline Official Restr $(+10)$ & & & & & & & & $\begin{array}{c}0.009 \\
(0.167)\end{array}$ \\
\hline Investment & & & & $\begin{array}{c}0.196^{* * *} \\
(5.205)\end{array}$ & $\begin{array}{c}0.196^{* * *} \\
(4.480)\end{array}$ & $\begin{array}{c}0.202^{* * * *} \\
(4.285)\end{array}$ & $\begin{array}{c}0.220^{* * *} \\
(4.308)\end{array}$ & $\begin{array}{c}0.229^{* * * *} \\
(3.886)\end{array}$ \\
\hline
\end{tabular}


(delta) Population

Secondary Edu

(log) Popolation

Government Cons.

Civil Liberties

(delta) Terms of Trade

Openness

Constant

Observations

Country FE

Time FE

R-squared

Number of id
Banking Crises

\begin{tabular}{|c|c|c|c|c|c|}
\hline & -0.106 & 0.024 & -0.071 & -0.117 & -0.308 \\
\hline & $(-0.283)$ & (0.059) & $(-0.165)$ & $(-0.259)$ & $(-0.689)$ \\
\hline & $-0.076^{* *}$ & $-0.081^{* *}$ & $-0.084^{*}$ & $-0.080^{*}$ & -0.075 \\
\hline & $(-2.207)$ & $(-2.134)$ & $(-1.964)$ & $(-1.785)$ & $(-1.666)$ \\
\hline & $-6.654^{* * *}$ & $-10.374^{* * *}$ & $-10.796^{* * *}$ & $-12.038^{* * *}$ & $-12.744^{* *}$ \\
\hline & $(-2.828)$ & $(-3.371)$ & $(-3.062)$ & $(-2.702)$ & $(-2.436)$ \\
\hline & $-0.230^{* * *}$ & $-0.244^{* * *}$ & $-0.251^{* * *}$ & $-0.231^{* * *}$ & $-0.223^{* * *}$ \\
\hline & $(-4.232)$ & $(-4.069)$ & $(-4.037)$ & $(-3.586)$ & $(-3.273)$ \\
\hline & $0.536^{* *}$ & $0.550^{* *}$ & $0.497^{*}$ & 0.381 & $0.505^{*}$ \\
\hline & $(2.324)$ & (2.274) & (1.970) & (1.374) & (1.838) \\
\hline & $0.397^{* * *}$ & $0.373^{* * *}$ & $0.361^{* * *}$ & $0.312^{* * *}$ & $0.332^{* * *}$ \\
\hline & $(4.344)$ & $(4.550)$ & $(4.440)$ & (5.149) & $(5.534)$ \\
\hline & -0.013 & -0.019 & -0.019 & -0.021 & -0.028 \\
\hline & $(-0.850)$ & $(-1.098)$ & $(-0.973)$ & $(-1.013)$ & $(-1.365)$ \\
\hline & $-1.497^{* * *}$ & $-1.400^{* *}$ & $-1.312^{* *}$ & $-1.391^{* *}$ & $-1.330^{* *}$ \\
\hline & $(-2.860)$ & $(-2.524)$ & $(-2.359)$ & $(-2.452)$ & $(-2.105)$ \\
\hline $885^{* * *} 3.884^{* * *} 3.890^{* * *}$ & $121.053^{* * *}$ & $184.186^{* * *} 1$ & $188.274^{* * *}$ & $208.958^{* * *}$ & $217.728^{* *}$ \\
\hline $\begin{array}{lll}(5.292) & (5.291) & (5.297)\end{array}$ & $(3.013)$ & (3.512) & (3.145) & $(2.764)$ & $(2.468)$ \\
\hline
\end{tabular}

Robust t-statistics in parentheses ${ }^{\star * *} p<0.01,{ }^{* *} p<0.05,{ }^{*} p<0.1$

\begin{tabular}{cccccccc}
3,480 & 3,479 & 3,479 & 1,383 & 1,279 & 1,184 & 1,081 & 938 \\
YES & YES & YES & YES & YES & YES & YES & YES \\
YES & YES & YES & YES & YES & YES & YES & YES \\
0.082 & 0.084 & 0.085 & 0.238 & 0.238 & 0.211 & 0.176 & 0.178 \\
117 & 117 & 117 & 72 & 68 & 67 & 67 & 64 \\
\hline
\end{tabular}




\begin{tabular}{|c|c|c|c|c|c|c|c|c|}
\hline & & $(-0.553)$ & & $(1.241)$ & & $(0.184)$ & & $(0.045)$ \\
\hline \multirow[t]{2}{*}{ Restructuring $(+9)$} & & 0.007 & & 0.051 & & 0.006 & & 0.013 \\
\hline & & $(0.309)$ & & (1.337) & & $(0.178)$ & & $(0.329)$ \\
\hline \multirow[t]{2}{*}{ Restructuring $(+10)$} & & $-0.055^{* *}$ & & 0.017 & & 0.007 & & 0.073 \\
\hline & & $(-2.649)$ & & $(0.451)$ & & $(0.132)$ & & $(0.728)$ \\
\hline \multirow[t]{2}{*}{ Growth $(-1)$} & $0.225^{* * *}$ & $0.178^{* * *}$ & & & $0.176^{* * *}$ & $0.133^{* *}$ & & \\
\hline & $(3.833)$ & $(2.955)$ & & & $(2.815)$ & $(2.378)$ & & \\
\hline \multirow[t]{2}{*}{ Investment } & $0.160^{* * *}$ & $0.185^{* * *}$ & $0.127^{* * *}$ & $0.126^{* * *}$ & $0.184^{* * *}$ & $0.201^{* * *}$ & $0.134^{* *}$ & $0.138^{* *}$ \\
\hline & $(3.661)$ & $(3.431)$ & $(3.054)$ & $(2.739)$ & $(3.241)$ & $(3.068)$ & $(2.655)$ & $(2.248)$ \\
\hline \multirow[t]{2}{*}{ (delta) Population } & -0.014 & -0.148 & -0.578 & -0.282 & -0.154 & -0.338 & -0.344 & 0.089 \\
\hline & $(-0.041)$ & $(-0.375)$ & $(-1.344)$ & $(-0.592)$ & $(-0.362)$ & $(-0.768)$ & $(-0.771)$ & $(0.159)$ \\
\hline \multirow[t]{2}{*}{ Secondary Edu } & $-0.059^{*}$ & $-0.067^{*}$ & $-0.066^{* *}$ & $-0.078^{*}$ & -0.065 & -0.069 & $-0.093^{* *}$ & -0.085 \\
\hline & $(-1.797)$ & $(-1.670)$ & $(-2.098)$ & $(-1.832)$ & $(-1.655)$ & $(-1.666)$ & $(-2.186)$ & $(-1.303)$ \\
\hline \multirow[t]{2}{*}{ (log) Popolation } & $-6.943^{* * *}$ & $-8.774^{* *}$ & -2.931 & -3.331 & $-9.411^{* *}$ & $-10.629^{* *}$ & -1.196 & 1.743 \\
\hline & $(-2.899)$ & $(-2.541)$ & $(-0.971)$ & $(-0.797)$ & $(-2.548)$ & $(-2.382)$ & $(-0.291)$ & $(0.312)$ \\
\hline \multirow[t]{2}{*}{ Government Cons. } & $-0.204^{* * *}$ & $-0.195^{* * *}$ & $-0.258^{* * *}$ & $-0.218^{* *}$ & $-0.202^{* * *}$ & $-0.202^{* * *}$ & $-0.253^{* *}$ & $-0.269^{* *}$ \\
\hline & $(-4.179)$ & $(-3.696)$ & $(-2.952)$ & $(-2.343)$ & $(-3.622)$ & $(-3.343)$ & $(-2.569)$ & $(-2.228)$ \\
\hline \multirow[t]{2}{*}{ Civil Liberties } & $0.380^{*}$ & 0.293 & -0.046 & -0.092 & 0.292 & $0.441^{*}$ & -0.156 & -0.197 \\
\hline & $(1.849)$ & $(1.264)$ & $(-0.153)$ & $(-0.256)$ & $(1.216)$ & $(1.762)$ & $(-0.475)$ & $(-0.489)$ \\
\hline \multirow[t]{2}{*}{ (delta) Terms of Trade } & $0.280^{* * *}$ & $0.280^{* * *}$ & $0.259^{* * *}$ & $0.290^{* * *}$ & $0.271^{* * *}$ & $0.304^{* * *}$ & $0.268^{* * *}$ & $0.280^{* * *}$ \\
\hline & $(4.473)$ & $(4.731)$ & (3.672) & (3.775) & $(4.491)$ & $(5.045)$ & $(3.878)$ & $(4.189)$ \\
\hline \multirow[t]{2}{*}{ Openness } & -0.016 & -0.018 & -0.020 & -0.017 & -0.018 & -0.024 & -0.016 & -0.015 \\
\hline & $(-1.125)$ & $(-1.048)$ & $(-1.524)$ & $(-1.096)$ & $(-0.933)$ & $(-1.234)$ & $(-1.001)$ & $(-0.817)$ \\
\hline \multirow[t]{2}{*}{ Banking Crises } & $-0.835^{*}$ & $-0.993^{*}$ & $-1.465^{* *}$ & $-1.724^{* * *}$ & $-1.102^{* *}$ & $-1.141^{*}$ & $-1.562^{* *}$ & $-1.462^{* *}$ \\
\hline & $(-1.718)$ & $(-1.903)$ & $(-2.439)$ & $(-2.986)$ & $(-2.240)$ & $(-1.989)$ & $(-2.598)$ & $(-2.058)$ \\
\hline \multirow[t]{2}{*}{ Currency Crises } & & & -1.568 & -1.391 & & & -1.307 & -0.810 \\
\hline & & & $(-1.099)$ & $(-1.034)$ & & & $(-0.900)$ & $(-0.561)$ \\
\hline \multirow[t]{2}{*}{ Debt to GDP } & & & -1.222 & $-2.341^{*}$ & & & $-1.989^{*}$ & -2.847 \\
\hline & & & $(-1.359)$ & $(-1.840)$ & & & $(-1.682)$ & $(-1.620)$ \\
\hline \multirow[t]{2}{*}{ Gov. Change } & & & $-0.861^{* *}$ & -0.610 & & & -0.447 & -0.638 \\
\hline & & & $(-2.136)$ & $(-1.336)$ & & & $(-0.999)$ & $(-1.224)$ \\
\hline \multirow[t]{2}{*}{ Inflation } & & & $0.057^{* * *}$ & $0.042^{*}$ & & & $0.060^{* * *}$ & $0.063^{*}$ \\
\hline & & & $(3.228)$ & (1.739) & & & $(2.805)$ & $(1.826)$ \\
\hline \multirow[t]{2}{*}{ Political Risk } & & & 0.023 & 0.026 & & & 0.023 & 0.012 \\
\hline & & & $(0.670)$ & $(0.721)$ & & & $(0.621)$ & $(0.289)$ \\
\hline \multirow[t]{2}{*}{ Constant } & $124.512^{* * *}$ & $153.606^{* *}$ & 56.963 & 64.620 & $164.182^{* *}$ & $183.685^{* *}$ & 28.441 & -21.810 \\
\hline & $(3.055)$ & (2.613) & (1.099) & $(0.906)$ & $(2.621)$ & $(2.439)$ & $(0.408)$ & $(-0.231)$ \\
\hline Observations & 1,221 & 1,076 & 637 & 533 & 1,070 & 927 & 527 & 435 \\
\hline Country FE & YES & YES & YES & YES & YES & YES & YES & YES \\
\hline Time FE & YES & YES & YES & YES & YES & YES & YES & YES \\
\hline R-squared & 0.265 & 0.213 & 0.281 & 0.271 & 0.198 & 0.190 & 0.227 & 0.241 \\
\hline Number of id & 67 & 67 & 47 & 46 & 67 & 64 & 46 & 46 \\
\hline
\end{tabular}

In columns (1) to (4), the dependent variable is the haircut, in columns (5) to (8) the dependent variable is official restructuring. Robust $\mathrm{t}$-statistics in parentheses, ${ }^{* * *} \mathrm{p}<0.01,{ }^{* *} \mathrm{p}<0.05,{ }^{*} \mathrm{p}<0.1$. 
Table 5: Reverse Causality (haircut)

\begin{tabular}{|c|c|c|c|c|c|c|c|c|c|}
\hline & $\begin{array}{c}\text { Haircut } \\
\text { (1) }\end{array}$ & $\begin{array}{c}\text { Haircut } \\
\text { (2) }\end{array}$ & $\begin{array}{c}\text { Haircut } \\
\text { (3) }\end{array}$ & $\begin{array}{c}\text { Haircut }(t+1) \\
(4)\end{array}$ & $\begin{array}{c}\text { Haircut }(t+1) \\
(5)\end{array}$ & $\begin{array}{c}\text { Haircut }(t+1) \\
(6)\end{array}$ & $\begin{array}{c}\text { Haircut }(\mathrm{t}+5) \\
(7)\end{array}$ & $\begin{array}{c}\text { Haircut }(t+5) \\
(8)\end{array}$ & $\begin{array}{c}\text { Haircut }(\mathrm{t}+5) \\
(9)\end{array}$ \\
\hline Growthpc (t-3) & & & $\begin{array}{c}0.015 \\
(0.158)\end{array}$ & & & & & & \\
\hline Growthpc (t-2) & & $\begin{array}{c}-0.064 \\
(-0.929)\end{array}$ & $\begin{array}{c}-0.071 \\
(-0.933)\end{array}$ & & & $\begin{array}{c}0.097 \\
(1.194)\end{array}$ & & & \\
\hline Growthpc (t-1) & $\begin{array}{c}0.056 \\
(1.130)\end{array}$ & $\begin{array}{c}0.075 \\
(1.352)\end{array}$ & $\begin{array}{c}0.068 \\
(1.139)\end{array}$ & & $\begin{array}{c}-0.067 \\
(-0.811)\end{array}$ & $\begin{array}{c}-0.094 \\
(-1.023)\end{array}$ & & & \\
\hline Growthpc & & & & $\begin{array}{c}0.026 \\
(0.449)\end{array}$ & $\begin{array}{c}0.045 \\
(0.701)\end{array}$ & $\begin{array}{c}0.034 \\
(0.489)\end{array}$ & & & \\
\hline Growthpc $(\mathrm{t}+2)$ & & & & & & & & & $\begin{array}{c}-0.090 \\
(-0.702)\end{array}$ \\
\hline Growthpc $(t+3)$ & & & & & & & & $\begin{array}{l}-0.174^{*} \\
(-1.917)\end{array}$ & $\begin{array}{c}-0.150 \\
(-1.571)\end{array}$ \\
\hline Growthpc $(\mathrm{t}+4)$ & & & & & & & $\begin{array}{c}0.026 \\
(0.363)\end{array}$ & $\begin{array}{c}0.071 \\
(0.914)\end{array}$ & $\begin{array}{c}0.072 \\
(0.912)\end{array}$ \\
\hline Observations & 1,473 & 1,429 & 1,381 & 1,485 & 1,473 & 1,429 & 1,336 & 1,335 & 1,334 \\
\hline Country FE & YES & YES & YES & YES & YES & YES & YES & YES & YES \\
\hline Time FE & YES & YES & YES & YES & YES & YES & YES & YES & YES \\
\hline Macro controls & YES & YES & YES & YES & YES & YES & YES & YES & YES \\
\hline R-squared & 0.067 & 0.069 & 0.069 & 0.053 & 0.054 & 0.056 & 0.038 & 0.043 & 0.044 \\
\hline Number of id & 73 & 73 & 73 & 73 & 73 & 73 & 70 & 70 & 70 \\
\hline
\end{tabular}

In columns (1) to (3), the dependent variable is the haircut, in columns (4) to (6) the dependent variable is the haircut at time $t+1$, while

in columns (7) to (9) the dependent variable is the haircut at time $t+5$. Robust $t$-statistics in parentheses, ${ }^{* * *} \mathrm{p}<0.01,{ }^{* *} \mathrm{p}<0.05,{ }^{*} \mathrm{p}<0.1$. 
Table 6: Reverse Causality (official restructuring)

Off res $\quad$ Off res $\quad$ Off res $\quad$ Off res $(t+1) \quad$ Off res $(t+1) \quad$ Off res $(t+1) \quad$ Off res $(t+5) \quad$ Off res $(t+5) \quad$ Off res $(t+5)$

(1)

(2) (3)

(4)

(5)

(6)

(7)

(8)

(9)

Growthpc (t-3)

$-0.030$

$(-1.139)$

Growthpc (t-2)

$-0.026 \quad-0.017$

$(-0.664) \quad(-0.409)$

Growthpc (t-1)

$0.128 \quad 0.140 \quad 0.151$

$(0.916) \quad(0.937) \quad(0.923)$

$\begin{array}{ccc} & & -0.020 \\ & & (-0.786) \\ & 0.010 & 0.015 \\ 0.104 & (0.298) & (0.431) \\ (0.761) & (0.723) & 0.109 \\ & & (0.708)\end{array}$

Growthpc

Growthpc $(\mathrm{t}+2)$

Growthpc $(\mathrm{t}+3)$

Growthpc (t+4)

Observations

Country FE

Time FE

Macro controls

R-squared

Number of id

$\begin{array}{cccc}1,422 & 1,378 & 1,330 & 1,384 \\ \text { YES } & \text { YES } & \text { YES } & \text { YES } \\ \text { YES } & \text { YES } & \text { YES } & \text { YES } \\ \text { YES } & \text { YES } & \text { YES } & \text { YES } \\ 0.036 & 0.035 & 0.036 & 0.026 \\ 72 & 72 & 72 & 72\end{array}$

$\begin{array}{cc}1,372 & 1,328 \\ \text { YES } & \text { YES } \\ \text { YES } & \text { YES } \\ \text { YES } & \text { YES } \\ 0.026 & 0.026 \\ 72 & 72\end{array}$

\begin{tabular}{ccc} 
& & -0.023 \\
& & $(-0.726)$ \\
& -0.064 & -0.058 \\
& $(-1.457)$ & $(-1.285)$ \\
0.155 & 0.171 & 0.171 \\
$(0.927)$ & $(0.988)$ & $(0.987)$ \\
& & \\
1,191 & 1,190 & 1,189 \\
YES & YES & YES \\
YES & YES & YES \\
YES & YES & YES \\
0.042 & 0.044 & 0.045 \\
67 & 67 & 67 \\
\hline
\end{tabular}

In columns (1) to (3), the dependent variable is official restructurings, in columns (4) to (6) the dependent variable is official restructurings at time $t+1$, in columns (7) to (9) the dependent variable is official restructurings at time $t+5$.

Robust t-statistics in parentheses, ${ }^{* * *} \mathrm{p}<0.01,{ }^{* *} \mathrm{p}<0.05,{ }^{*} \mathrm{p}<0.1$. 
Table 7: Haircuts and Credit Rating, 1990-2013, OLS

\begin{tabular}{|c|c|c|c|c|c|c|c|c|}
\hline & $(1)$ & $\overline{(2)}$ & $\overline{(3)}$ & $\overline{(4)}$ & $\overline{(5)}$ & $\overline{(6)}$ & $(7)$ & $\overline{(8)}$ \\
\hline Haircut dummy (-1) & $\begin{array}{l}-1.300^{*} \\
(-1.816)\end{array}$ & & $\begin{array}{c}-0.936 \\
(-1.317)\end{array}$ & $\begin{array}{c}0.173 \\
(0.250)\end{array}$ & $\begin{array}{c}-0.529 \\
(-0.671)\end{array}$ & $\begin{array}{c}0.328 \\
(0.451)\end{array}$ & $\begin{array}{c}-0.217 \\
(-0.260)\end{array}$ & $\begin{array}{c}-0.014 \\
(-0.021)\end{array}$ \\
\hline Haircut dummy & $\begin{array}{c}-1.753^{* *} \\
(-2.618)\end{array}$ & & $\begin{array}{l}-1.489^{* *} \\
(-2.010)\end{array}$ & $\begin{array}{c}-1.283 \\
(-1.354)\end{array}$ & $\begin{array}{c}-0.869 \\
(-0.923)\end{array}$ & $\begin{array}{c}-1.052 \\
(-1.416)\end{array}$ & $\begin{array}{c}-0.701 \\
(-0.628)\end{array}$ & $\begin{array}{c}-0.707 \\
(-0.890)\end{array}$ \\
\hline Haircut dummy $(+1)$ & $\begin{array}{c}-3.113^{* * *} \\
(-4.515)\end{array}$ & & $\begin{array}{c}-1.536 \\
(-1.065)\end{array}$ & $\begin{array}{l}-2.570^{* *} \\
(-2.534)\end{array}$ & $\begin{array}{c}-0.888 \\
(-0.540)\end{array}$ & $\begin{array}{l}-2.349^{* *} \\
(-2.038)\end{array}$ & $\begin{array}{c}-0.600 \\
(-0.368)\end{array}$ & $\begin{array}{l}-2.467^{*} \\
(-1.667)\end{array}$ \\
\hline Haircut dummy (+2) & & & & & $\begin{array}{c}1.562 \\
(1.019)\end{array}$ & $\begin{array}{c}0.711 \\
(0.637)\end{array}$ & $\begin{array}{c}1.773 \\
(1.238)\end{array}$ & $\begin{array}{c}0.826 \\
(0.692)\end{array}$ \\
\hline Haircut dummy $(+3)$ & & & & & $\begin{array}{c}2.903^{* * *} \\
(2.670)\end{array}$ & $\begin{array}{c}2.257 \\
(0.853)\end{array}$ & $\begin{array}{l}3.492^{* *} \\
(2.623)\end{array}$ & $\begin{array}{c}2.448 \\
(0.960)\end{array}$ \\
\hline Haircut dummy (+4 \& 5) & & & & & & & $\begin{array}{c}1.397 \\
(0.993)\end{array}$ & $\begin{array}{c}3.799^{* * *} \\
(3.030)\end{array}$ \\
\hline Haircut dummy (+6 \& 7) & & & & & & & $\begin{array}{c}2.645^{* * *} \\
(3.820)\end{array}$ & $\begin{array}{c}1.169 \\
(1.374)\end{array}$ \\
\hline Haircut (-1) & & $\begin{array}{l}-0.025^{* *} \\
(-2.091)\end{array}$ & $\begin{array}{c}-0.010 \\
(-0.866)\end{array}$ & $\begin{array}{c}-0.012 \\
(-0.999)\end{array}$ & $\begin{array}{c}-0.018 \\
(-1.265)\end{array}$ & $\begin{array}{c}-0.015 \\
(-1.250)\end{array}$ & $\begin{array}{l}-0.030 * * \\
(-2.340)\end{array}$ & $\begin{array}{c}-0.017 \\
(-1.490)\end{array}$ \\
\hline Haircut & & $\begin{array}{l}-0.025^{* *} \\
(-2.213)\end{array}$ & $\begin{array}{c}-0.003 \\
(-0.174)\end{array}$ & $\begin{array}{c}0.008 \\
(0.487)\end{array}$ & $\begin{array}{c}-0.015 \\
(-0.710)\end{array}$ & $\begin{array}{c}0.003 \\
(0.153)\end{array}$ & $\begin{array}{c}-0.020 \\
(-0.742)\end{array}$ & $\begin{array}{c}0.003 \\
(0.106)\end{array}$ \\
\hline Haircut (+1) & & $\begin{array}{c}-0.063^{* * *} \\
(-3.542)\end{array}$ & $\begin{array}{c}-0.037 \\
(-1.112)\end{array}$ & $\begin{array}{c}0.000 \\
(0.029)\end{array}$ & $\begin{array}{c}-0.051 \\
(-1.525)\end{array}$ & $\begin{array}{c}-0.005 \\
(-0.299)\end{array}$ & $\begin{array}{l}-0.060^{*} \\
(-1.797)\end{array}$ & $\begin{array}{c}-0.016 \\
(-0.794)\end{array}$ \\
\hline Haircut (+2) & & & & & $\begin{array}{l}-0.052^{* *} \\
(-2.406)\end{array}$ & $\begin{array}{c}-0.022 \\
(-1.177)\end{array}$ & $\begin{array}{c}-0.064^{* * *} \\
(-3.047)\end{array}$ & $\begin{array}{l}-0.063^{* *} \\
(-2.152)\end{array}$ \\
\hline Haircut (+3) & & & & & $\begin{array}{l}-0.061^{* *} \\
(-2.459)\end{array}$ & $\begin{array}{c}-0.023 \\
(-0.647)\end{array}$ & $\begin{array}{l}-0.072^{* *} \\
(-2.185)\end{array}$ & $\begin{array}{c}-0.051 \\
(-1.397)\end{array}$ \\
\hline Haircut (+4 \& 5) & & & & & & & $\begin{array}{l}-0.044^{* *} \\
(-2.012)\end{array}$ & $\begin{array}{l}-0.066^{* *} \\
(-2.362)\end{array}$ \\
\hline Haircut (+6 \& 7) & & & & & & & $\begin{array}{c}-0.025 \\
(-1.132)\end{array}$ & $\begin{array}{c}-0.026 \\
(-1.436)\end{array}$ \\
\hline Public debt to GDP & & & & $\begin{array}{l}-0.026^{* *} \\
(-2.052)\end{array}$ & & $\begin{array}{l}-0.022^{* *} \\
(-2.023)\end{array}$ & & $\begin{array}{c}-0.036^{* * *} \\
(-4.094)\end{array}$ \\
\hline Per capita GDP (log) & & & & $\begin{array}{c}4.446^{* * *} \\
(5.294)\end{array}$ & & $\begin{array}{c}5.019^{* * *} \\
(5.333)\end{array}$ & & $\begin{array}{c}6.903^{* * *} \\
(4.100)\end{array}$ \\
\hline GDP real growth & & & & $\begin{array}{c}-0.013 \\
(-0.789)\end{array}$ & & $\begin{array}{c}-0.009 \\
(-0.495)\end{array}$ & & $\begin{array}{c}-0.039 \\
(-1.269)\end{array}$ \\
\hline (log) Popolation & & & & $\begin{array}{c}0.877 \\
(0.633)\end{array}$ & & $\begin{array}{c}1.723 \\
(1.378)\end{array}$ & & $\begin{array}{c}-0.374 \\
(-0.142)\end{array}$ \\
\hline Reserves to imports & & & & $\begin{array}{c}-0.011 \\
(-0.289)\end{array}$ & & $\begin{array}{c}-0.013 \\
(-0.358)\end{array}$ & & $\begin{array}{c}0.012 \\
(0.282)\end{array}$ \\
\hline Inflation & & & & $\begin{array}{c}-7.431^{* * *} \\
(-4.321)\end{array}$ & & $\begin{array}{c}-8.538^{* * *} \\
(-5.198)\end{array}$ & & $\begin{array}{c}-5.645^{* * *} \\
(-2.729)\end{array}$ \\
\hline Current Account to GDP & & & & $\begin{array}{l}-0.025^{* *} \\
(-2.109)\end{array}$ & & $\begin{array}{c}-0.040^{* * *} \\
(-3.327)\end{array}$ & & $\begin{array}{c}-0.058^{* * *} \\
(-3.083)\end{array}$ \\
\hline (Absence of) Political risk & & & & $\begin{array}{c}0.107^{* * *} \\
(3.218)\end{array}$ & & $\begin{array}{l}0.081^{* *} \\
(2.500)\end{array}$ & & $\begin{array}{c}0.031 \\
(0.992)\end{array}$ \\
\hline
\end{tabular}




\begin{tabular}{|c|c|c|c|c|c|c|c|c|}
\hline Years in Office & & & & $\begin{array}{c}0.009 \\
(0.632)\end{array}$ & & $\begin{array}{c}-0.008 \\
(-0.727)\end{array}$ & & $\begin{array}{c}0.002 \\
(0.103)\end{array}$ \\
\hline \multirow[t]{2}{*}{ Fitch } & & & & $-0.246^{* *}$ & & -0.035 & & -0.089 \\
\hline & & & & $(-2.093)$ & & $(-0.290)$ & & $(-0.537)$ \\
\hline \multirow[t]{2}{*}{ Moody's } & & & & -0.183 & & -0.098 & & -0.078 \\
\hline & & & & $(-1.514)$ & & $(-0.786)$ & & $(-0.563)$ \\
\hline \multirow[t]{2}{*}{ Standard and Poor's } & & & & $-0.460^{* * *}$ & & $-0.376^{* *}$ & & $-0.316^{*}$ \\
\hline & & & & $(-3.080)$ & & $(-2.312)$ & & $(-1.769)$ \\
\hline \multirow[t]{2}{*}{ Constant } & $11.062^{* * *}$ & $11.054^{* * *}$ & $11.057^{* * *}$ & $-59.931^{* *}$ & $11.427^{* * *}$ & $-79.315^{* *}$ & $11.464^{* * *}$ & -62.122 \\
\hline & $(40.644)$ & $(40.433)$ & $(40.380)$ & $(-2.539)$ & $(56.991)$ & $(-3.689)$ & $(52.139)$ & $(-1.174)$ \\
\hline Observations & 891 & 891 & 891 & 617 & 790 & 537 & 586 & 365 \\
\hline Country FE & YES & YES & YES & YES & YES & YES & YES & YES \\
\hline Time FE & YES & YES & YES & YES & YES & YES & YES & YES \\
\hline R-squared & 0.312 & 0.310 & 0.318 & 0.540 & 0.361 & 0.571 & 0.398 & 0.626 \\
\hline Number of id & 70 & 70 & 70 & 59 & 70 & 59 & 69 & 55 \\
\hline
\end{tabular}

Robust t-statistics in parentheses ${ }^{* * *} \mathrm{p}<0.01,{ }^{* *} \mathrm{p}<0.05,{ }^{*} \mathrm{p}<0.1$ 


\begin{tabular}{|c|c|c|c|c|c|c|c|c|}
\hline & $(1)$ & $(2)$ & $(3)$ & $(\overline{(4)}$ & 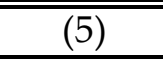 & 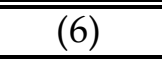 & $(7)$ & $\overline{(8)}$ \\
\hline Off. Restr. dummy (-1) & $\begin{array}{c}-0.334 \\
(-0.888)\end{array}$ & & $\begin{array}{c}-0.480 \\
(-1.134)\end{array}$ & $\begin{array}{c}-0.267 \\
(-0.655)\end{array}$ & $\begin{array}{c}-0.873 \\
(-1.523)\end{array}$ & $\begin{array}{c}-0.464 \\
(-0.999)\end{array}$ & $\begin{array}{c}-1.109 \\
(-1.441)\end{array}$ & $\begin{array}{l}-1.083^{*} \\
(-1.830)\end{array}$ \\
\hline Off. Restr. dummy & $\begin{array}{c}-0.876 \\
(-1.317)\end{array}$ & & $\begin{array}{c}-1.146 \\
(-1.472)\end{array}$ & $\begin{array}{c}-0.427 \\
(-0.843)\end{array}$ & $\begin{array}{l}-1.586^{*} \\
(-1.886)\end{array}$ & $\begin{array}{c}-0.549 \\
(-1.077)\end{array}$ & $\begin{array}{l}-3.945^{* *} \\
(-2.459)\end{array}$ & $\begin{array}{l}-2.421^{*} \\
(-1.974)\end{array}$ \\
\hline Off. Restr. dummy $(+1)$ & $\begin{array}{l}-1.758^{* *} \\
(-2.481)\end{array}$ & & $\begin{array}{l}-1.955^{* *} \\
(-2.410)\end{array}$ & $\begin{array}{c}-0.591 \\
(-0.774)\end{array}$ & $\begin{array}{c}-2.330^{* * *} \\
(-2.798)\end{array}$ & $\begin{array}{c}-0.778 \\
(-1.143)\end{array}$ & $\begin{array}{c}-2.738^{* * *} \\
(-2.984)\end{array}$ & $\begin{array}{l}-2.166^{*} \\
(-1.954)\end{array}$ \\
\hline Off. Restr. dummy (+2) & & & & & $\begin{array}{c}0.107 \\
(0.228)\end{array}$ & $\begin{array}{c}-0.050 \\
(-0.064)\end{array}$ & $\begin{array}{c}-0.553 \\
(-1.054)\end{array}$ & $\begin{array}{c}-0.578 \\
(-0.562)\end{array}$ \\
\hline Off. Restr. dummy (+3) & & & & & $\begin{array}{l}1.447^{* *} \\
(2.330)\end{array}$ & $\begin{array}{c}-0.083 \\
(-0.083)\end{array}$ & $\begin{array}{c}0.908 \\
(1.305)\end{array}$ & $\begin{array}{c}-0.091 \\
(-0.085)\end{array}$ \\
\hline Off. Restr dummy (+4 \& 5) & & & & & & & $\begin{array}{c}0.322 \\
(0.309)\end{array}$ & $\begin{array}{c}-1.283 \\
(-0.990)\end{array}$ \\
\hline Off. Restr dummy (+6 \& 7) & & & & & & & $\begin{array}{c}1.367 \\
(1.485)\end{array}$ & $\begin{array}{c}0.199 \\
(0.153)\end{array}$ \\
\hline Official Restr (-1) & & $\begin{array}{c}0.003 \\
(0.794)\end{array}$ & $\begin{array}{l}0.012^{* *} \\
(2.023)\end{array}$ & $\begin{array}{c}0.007 \\
(1.246)\end{array}$ & $\begin{array}{c}0.030 \\
(1.008)\end{array}$ & $\begin{array}{c}-0.012 \\
(-0.588)\end{array}$ & $\begin{array}{c}0.034 \\
(0.981)\end{array}$ & $\begin{array}{c}0.017 \\
(0.878)\end{array}$ \\
\hline Official Restr & & $\begin{array}{c}-0.012 \\
(-0.480)\end{array}$ & $\begin{array}{c}0.043 \\
(1.094)\end{array}$ & $\begin{array}{c}-0.008 \\
(-0.481)\end{array}$ & $\begin{array}{c}0.050 \\
(1.046)\end{array}$ & $\begin{array}{c}-0.025 \\
(-1.082)\end{array}$ & $\begin{array}{l}0.469^{* *} \\
(2.328)\end{array}$ & $\begin{array}{c}0.203^{*} \\
(1.884)\end{array}$ \\
\hline Official Restr (+1) & & $\begin{array}{l}-0.054^{*} \\
(-1.810)\end{array}$ & $\begin{array}{c}0.029 \\
(0.699)\end{array}$ & $\begin{array}{c}-0.006 \\
(-0.180)\end{array}$ & $\begin{array}{c}0.040 \\
(0.727)\end{array}$ & $\begin{array}{c}-0.025 \\
(-0.664)\end{array}$ & $\begin{array}{c}0.148 \\
(1.379)\end{array}$ & $\begin{array}{c}0.136^{*} \\
(1.809)\end{array}$ \\
\hline Official Restr (+2) & & & & & $\begin{array}{c}-0.004 \\
(-0.167)\end{array}$ & $\begin{array}{c}-0.032 \\
(-1.475)\end{array}$ & $\begin{array}{c}-0.003 \\
(-0.142)\end{array}$ & $\begin{array}{c}-0.017 \\
(-0.423)\end{array}$ \\
\hline Official Restr (+3) & & & & & $\begin{array}{c}-0.019 \\
(-0.356)\end{array}$ & $\begin{array}{c}-0.027 \\
(-0.507)\end{array}$ & $\begin{array}{l}-0.087^{* *} \\
(-2.356)\end{array}$ & $\begin{array}{c}-0.107^{* * *} \\
(-4.043)\end{array}$ \\
\hline Official Restr (+4 \& 5) & & & & & & & $\begin{array}{c}0.004 \\
(0.136)\end{array}$ & $\begin{array}{c}0.006 \\
(0.135)\end{array}$ \\
\hline Official Restr (+6 \& 7) & & & & & & & $\begin{array}{c}-0.012 \\
(-0.320)\end{array}$ & $\begin{array}{c}0.017 \\
(0.442)\end{array}$ \\
\hline Public debt to GDP & & & & $\begin{array}{c}-0.022 \\
(-1.476)\end{array}$ & & $\begin{array}{c}-0.022 \\
(-1.420)\end{array}$ & & $\begin{array}{c}-0.023 \\
(-1.595)\end{array}$ \\
\hline Per capita GDP (log) & & & & $\begin{array}{c}5.824^{* * *} \\
(5.634)\end{array}$ & & $\begin{array}{c}6.814^{* * *} \\
(5.356)\end{array}$ & & $\begin{array}{c}9.099 * * * \\
(3.203)\end{array}$ \\
\hline GDP real growth & & & & $\begin{array}{c}-0.026 \\
(-1.098)\end{array}$ & & $\begin{array}{l}-0.056^{*} \\
(-1.712)\end{array}$ & & $\begin{array}{l}-0.078^{*} \\
(-1.727)\end{array}$ \\
\hline (log) Popolation & & & & $\begin{array}{c}1.198 \\
(0.623)\end{array}$ & & $\begin{array}{c}1.475 \\
(0.609)\end{array}$ & & $\begin{array}{c}2.913 \\
(0.873)\end{array}$ \\
\hline Reserves to imports & & & & $\begin{array}{c}-0.004 \\
(-0.087)\end{array}$ & & $\begin{array}{c}0.006 \\
(0.122)\end{array}$ & & $\begin{array}{c}0.036 \\
(0.835)\end{array}$ \\
\hline Inflation & & & & $\begin{array}{c}-9.285^{* * *} \\
(-4.183)\end{array}$ & & $\begin{array}{c}-8.968^{* * *} \\
(-3.693)\end{array}$ & & $\begin{array}{c}-7.891^{* *} \\
(-2.479)\end{array}$ \\
\hline Current Account to GDP & & & & $\begin{array}{c}-0.044^{* * *} \\
(-3.461)\end{array}$ & & $\begin{array}{l}-0.046^{* *} \\
(-2.582)\end{array}$ & & $\begin{array}{l}-0.075^{* *} \\
(-2.188)\end{array}$ \\
\hline (Absence of) Political risk & & & & $\begin{array}{l}0.083^{* *} \\
(2.628)\end{array}$ & & $\begin{array}{l}0.069^{* *} \\
(2.223)\end{array}$ & & $\begin{array}{l}0.071^{* *} \\
(2.021)\end{array}$ \\
\hline
\end{tabular}



Appendix 
Table A1: Country sample, defaulters

Haircut (cont'd)

Albania: 1991-1995

Algeria: 1991-1996

Argentina: 1982-1993; 2001-2005

Bolivia: 1980-1993

Brazil: 1983-1994

Bulgaria: 1990-1994

Cameroon: 1985-2003

Chile: $1983-1990$

Congo, Dem. Republic: 1980-1989

Congo, Republic: 1980-1988; 2007

Costa Rica: 1981-1990

Cote d'Ivoire: 1983-1998; 2000-2012

Cuba: 1980-1985

Dominican Republic: 1982-1994; 2004-2005

Ecuador: 1982-1995; 1999-2000; 2008-2009

Ethiopia: 1991-1996

Gabon: 1985-1994

Gambia: 1985-1988

Guinea: 1986-1998

Jamaica: 1975-1990

Jordan: 1989-1993

Kenya: 1994-1998

Liberia: 1980-1982; 2009

Madagascar: 1981-1990

Malawi: 1980-1988

Mauritania: 1992-1996

Mexico: 1982-1990

Moldova: 1998-2002

Morocco: 1983-1990

Mozambique: 1983-1992

Nicaragua: 1979-2007

Niger: 1983-1991

Nigeria: 1982-1992

Pakistan: 1998-1999

Panama: 1983-1996

Paraguay: 1986-1993

Peru: 1983-1997

Philippines: 1983-1992

Poland: 1991-1994

Romania: 1981-1983; 1986

Russia: 1991-2000

Senegal: 1980-85; 1990-96

Sierra Leone: 1986-95

South Africa: 1985-1987; 1989; 1993
Sudan: 1985

Tanzania: 2004

Togo: 1985-88; 1997

Turkey: 1981-1982

Uganda: 1980-93

Ukraine: 1998-2000

Uruguay: 1983-1991; 2003

Venezuela: 1982-1990; 2004-2005

Vietnam: 1997

Yemen: 1985-2001

Zambia: 1983-94 
Table A1 (cont'd): Country sample, defaulters

Official Rescheduling (cont'd) Non defaulters

Albania: 1993-2000

Algeria: 1994-95

Angola: 1989

Argentina: 1985-92

Benin: 1989-2003

Bolivia: 1986-2001

Brazil: 1983-92

Bulgaria: 1991-94

Burkina Faso: 1991-2002

Burundi: 2004-2009

Cambodia: 1995

Cameroon: 1989-2006

Central African Republic: 1981-2009

Chad: 1989-2001

Chile: $1975-87$

Congo, Dem. Rep.: 1976-89; 2002-10

Congo, Republic: 1986-94; 1996-10

Costa Rica: 1983-93

Cote d'Ivoire: 1984-94; 1998-2009

Cuba: 1986-86

Dominican Republic: 1985-2005

Ecuador: 1983-2003

Egypt: 1987-91

El Salvador: 1990

Ethiopia: 1992-2004

Gabon: 1987-95; 2000-04

Gambia: 1986; 2007-08

Georgia: 2001-04

Ghana: 1996-2004

Guinea: 1986-95; 1997-2008

Guinea-Bissau: 1987-95; 2001-10

Haiti: 1995-2009

Indonesia: 1994-2005

Jamaica: 1984-93

Jordan: 1989-2002

Kenya: 1994-2004

Kyrgyz Republic: 2002-05

Liberia: 1980-1984; 2008-10

Madagascar: 1981-90; 197-2004

Malawi: 1982-88: 2001-06

Mali: 1988-96; 2000-03

Mauritania: 1985-95; 2000-02

Mexico: 1983-89

Moldova: 2006

Morocco: 1983-92
Mozambique: 1984-96; 1999-2001
Nicaragua: 1991-95; 1998-2004
Niger: 1983-96; 2001-2004
Nigeria: 1986-91; 2000-05
Pakistan: 1981; 1989-2001
Panama: 1985-90
Peru: 1978-96
Philippines: 1984-94
Poland: 1981-91
Romania: 1982-83
Russia: 1993-99
Rwanda: 1998-2005
Senegal: 1981-95; 1998-2004
Sierra Leone: 1977-96; 2001-2007
Sri Lanka: 2005
Sudan: 1979-84
Tanzania: 1986-92; 1997-2002
Togo: 1979-95; 2008-09
Turkey: 1978-80
Uganda: 1981-83; 1989-2000
Ukraine: 2001
Vietnam: 1993
Yemen: 1996-2001
Zambia; 1983-92; 1996-2005

Armenia

Azerbaijan

Bahrain

Bangladesh

Belarus

Botswana

China

Colombia

Eritrea

Hong Kong

Hungary

India

Iran, Islamic Rep.

Kazakhstan

Kuwait

Lao PDR

Latvia

Lebanon

Lesotho

Libya

Lithuania

Malaysia

Mauritius

Mongolia

Myanmar

Namibia

Nepal

Oman

Papua New Guinea

Puerto Rico

Qatar

Saudi Arabia

Singapore

Slovak Rep

Swaziland

Syrian Arab Rep.

Tajikistan

Thailand

Tunisia

Turkmenistan

United Arab Em.

Uzbekistan

West Bank and Gaza

Zimbabwe 
Table A2: Variable definitions and sources

\begin{tabular}{|c|c|c|}
\hline Variable & Definition & Source \\
\hline \multicolumn{3}{|c|}{ DEPENDENT VARIABLE } \\
\hline GDP growth & Per capita GDP (constant 2005 US\$), Annual rate of change & GDP growth \\
\hline \multicolumn{3}{|c|}{ VARIABLES OF INTEREST } \\
\hline Haircut & Private debt restructurings, in percent & Cruces and Trebesch (2013) \\
\hline Haircut Dummy & Dummy $=1$ in case of an haircut & Built by the author \\
\hline Official Restructuring & Official debt restructurings, percent of total external debt & Das, Papaioannou and Trebesch (2011) \\
\hline Official Dummy & Dummy $=1$ in case of an official restructuring & Built by the author \\
\hline \multicolumn{3}{|c|}{ CONTROL VARIABLES } \\
\hline Investment & Gross fixed capital formation, ratio to GDP & WDI (2015) \\
\hline Gov. Consumption & Gen. government final consumption expenditure, ratio to GDP & WDI (2015) \\
\hline Openness & Exports plus imports of goods and services, ratio to GDP & WDI (2015) \\
\hline Inflation & Consumer price index $(2010=100)$, Annual rate of change & WDI (2015) \\
\hline External debt to GDP & Ratio of external debt to GDP & WDI (2015) \\
\hline Political Risk & ICRG Political Risk Index & ICRG (2013) \\
\hline Government change & $\begin{array}{l}\text { Dummy variable with a value of one } \\
\text { in years with a change in the executive }\end{array}$ & Database of Political Institutions (2012) \\
\hline (delta) Population & Rate of population growth, annual & WDI (2015) \\
\hline (log) Popolation & Log of total population & WDI (2015) \\
\hline Secondary Education & Percentage of the population that completed secondary education & WDI (2015) \\
\hline (delta) Terms of Trade & Annual change in terms-of-trade (in million) & WDI (2015) \\
\hline Banking crisis & Dummy equal 1 in the case of a banking crisis, 0 otherwise & Laeven and Valencia (2013) \\
\hline Currency crisis & Dummy equal 1 in the case of a currency crisis, 0 otherwise & Laeven and Valencia (2013) \\
\hline Civil Liberties & the Freedom House index of civil liberties, range goes from- 1 to 7 & Freedom House (2015) \\
\hline
\end{tabular}


Table A2 (cont'd): Variable definitions and sources

\begin{tabular}{|c|c|c|}
\hline Variable & Definition & Source \\
\hline \multicolumn{3}{|c|}{ DEPENDENT VARIABLE } \\
\hline FMSP & Pooled credit rating by Fitch, Moody's and Standard and Poor's & Built by the author \\
\hline Credit Index & Institutional Investor's crediworthiness index & Reinhart and Rogoff (2009) \\
\hline \multicolumn{3}{|c|}{ VARIABLES OF INTEREST } \\
\hline Haircut & Private debt restructurings, in percent & Cruces and Trebesch (2013) \\
\hline Haircut Dummy & Dummy $=1$ in case of an haircut & Built by the author \\
\hline Official Restructuring & Official debt restructurings, percent of total external debt & Das, Papaioannou and Trebesch (2011) \\
\hline Official Dummy & Dummy $=1$ in case of an official restructuring & Built by the author \\
\hline \multicolumn{3}{|l|}{ CONTROL VARIABLES } \\
\hline Public debt to GDP & General government gross debt & WDI (2015) \\
\hline Net lending/borrowing & General government net lending/borrowing & IMF, WEO Database (2013) \\
\hline Per capita GDP & Per capita GDP (constant 2005 US\$) & WDI (2015) \\
\hline GDP real growth & GDP (constant 2005 US\$), Annual rate of change & WDI (2015) \\
\hline (log) Popolation & Log of total population & WDI (2015) \\
\hline Reserves to Imports & Ratio of external debt to GDP & IFS (2015) \\
\hline Inflation & Consumer price index $(2010=100)$, Annual rate of change & WDI (2015) \\
\hline Current Account & Current account to GDP & WDI (2015) \\
\hline Political Risk & ICRG Political Risk Index & ICRG (2013) \\
\hline Years in office & Chief executive years in office & Database of Political Institutions (2012) \\
\hline $\mathrm{F}$ & dummy $=1$ if credit ratings is made by Fitch & Fitch rating \\
\hline M & dummy $=1$ if credit ratings is made by Moody's & Moody's rating \\
\hline SP & dummy $=1$ if credit ratings is made by Standard and Poor's & Standard and Poor's rating \\
\hline
\end{tabular}




\begin{tabular}{|c|c|c|c|c|}
\hline Variable & Mean & $\mathrm{SD}$ & Min & Max \\
\hline Haircut (-1) & 1.31 & 8.62 & 0 & 103.5 \\
\hline Haircut & 1.28 & 8.51 & 0 & 103.5 \\
\hline Haircut $(+1)$ & 1.31 & 8.62 & 0 & 103.5 \\
\hline Haircut (+2) & 1.35 & 8.73 & 0 & 103.5 \\
\hline Haircut (+3) & 1.38 & 8.85 & 0 & 103.5 \\
\hline Haircut $(+4)$ & 1.42 & 8.97 & 0 & 103.5 \\
\hline Haircut $(+5)$ & 1.46 & 9.1 & 0 & 103.5 \\
\hline Haircut $(+6)$ & 1.49 & 9.21 & 0 & 103.5 \\
\hline Haircut (+7) & 1.51 & 9.31 & 0 & 103.5 \\
\hline Haircut $(+8)$ & 1.49 & 9.22 & 0 & 102.3 \\
\hline Haircut (+9) & 1.49 & 9.28 & 0 & 102.3 \\
\hline Haircut $(+10)$ & 1.45 & 9.29 & 0 & 102.3 \\
\hline Haircut dummy $(-1)$ & 0.03 & 0.18 & 0 & 1 \\
\hline Haircut dummy & 0.03 & 0.18 & 0 & 1 \\
\hline Haircut dummy (+1) & 0.03 & 0.18 & 0 & 1 \\
\hline Haircut dummy (+2) & 0.03 & 0.18 & 0 & 1 \\
\hline Haircut dummy (+3) & 0.04 & 0.18 & 0 & 1 \\
\hline Haircut dummy $(+4)$ & 0.04 & 0.19 & 0 & 1 \\
\hline Haircut dummy (+5) & 0.04 & 0.19 & 0 & 1 \\
\hline Haircut dummy (+6) & 0.04 & 0.19 & 0 & 1 \\
\hline Haircut dummy (+7) & 0.04 & 0.19 & 0 & 1 \\
\hline Haircut dummy $(+8)$ & 0.04 & 0.19 & 0 & 1 \\
\hline Haircut dummy (+9) & 0.04 & 0.19 & 0 & 1 \\
\hline Haircut dummy $(+10)$ & 0.03 & 0.18 & 0 & 1 \\
\hline Official restr. $(-1)$ & 0.95 & 7.2 & 0 & 326.13 \\
\hline Official restr. & 0.95 & 7.2 & 0 & 326.13 \\
\hline Official restr. $(+1)$ & 0.98 & 7.3 & 0 & 326.13 \\
\hline Official restr. $(+2)$ & 1.01 & 7.4 & 0 & 326.13 \\
\hline Official restr. $(+3)$ & 1.03 & 7.51 & 0 & 326.13 \\
\hline Official restr. $(+4)$ & 1.06 & 7.62 & 0 & 326.13 \\
\hline Official restr. $(+5)$ & 1.08 & 7.72 & 0 & 326.13 \\
\hline Official restr. $(+6)$ & 1.1 & 7.84 & 0 & 326.13 \\
\hline Official restr. $(+7)$ & 1.12 & 7.95 & 0 & 326.13 \\
\hline Official restr. $(+8)$ & 1.15 & 8.09 & 0 & 326.13 \\
\hline Official restr. $(+9)$ & 1.15 & 8.2 & 0 & 326.13 \\
\hline Official restr. $(+10)$ & 1.18 & 8.35 & 0 & 326.13 \\
\hline Official restr. dummy $(-1)$ & 0.08 & 0.28 & 0 & 1 \\
\hline Official restr. dummy & 0.08 & 0.28 & 0 & 1 \\
\hline Official restr. dummy $(+1)$ & 0.09 & 0.28 & 0 & 1 \\
\hline Official restr. dummy $(+2)$ & 0.09 & 0.28 & 0 & 1 \\
\hline Official restr. dummy $(+3)$ & 0.09 & 0.29 & 0 & 1 \\
\hline Official restr. dummy $(+4)$ & 0.09 & 0.29 & 0 & 1 \\
\hline Official restr. dummy $(+5)$ & 0.1 & 0.29 & 0 & 1 \\
\hline
\end{tabular}




\begin{tabular}{lcccc} 
Official restr. dummy (+6) & 0.1 & 0.3 & 0 & 1 \\
Official restr. dummy $(+7)$ & 0.1 & 0.3 & 0 & 1 \\
Official restr. dummy $(+8)$ & 0.1 & 0.3 & 0 & 1 \\
Official restr. dummy (+9) & 0.1 & 0.3 & 0 & 1 \\
Official restr. dummy $(+10)$ & 0.1 & 0.3 & 0 & 1 \\
Growth & 1.69 & 6.52 & -62.47 & 102.78 \\
Investment & 22.33 & 8.87 & -5.74 & 74.82 \\
(delta) Population & 2.06 & 1.61 & -7.6 & 17.48 \\
Secondary Edu & 53.87 & 30.27 & 0.64 & 122.9 \\
(log) Popolation & 16.1 & 1.44 & 12.01 & 21.06 \\
Government Cons. & 15.06 & 6.98 & 0 & 86.91 \\
Civil Liberties & 4.49 & 1.55 & 1 & 7 \\
(delta) Terms of Trade & -0.99 & 0.62 & -19.27 & 20.86 \\
Openness & 76.67 & 51.76 & 0 & 455.28 \\
Banking Crises & 0.1 & 0.3 & 0 & 1 \\
Currency Crises & 0.04 & 0.2 & 0 & 1 \\
External debt to GDP & 0.66 & 0.91 & 0 & 18.97 \\
Gov. Change & 0.14 & 0.34 & 0 & 1 \\
Inflation & 44.12 & 515.05 & -13.06 & 23773.1 \\
Political Risk & 59.25 & 12.25 & 0 & 89.13 \\
\hline \hline
\end{tabular}




\begin{tabular}{|c|c|c|c|c|}
\hline Variable & Mean & SD & Min & Max \\
\hline Haircut (-1) & 1.31 & 8.62 & 0 & 103.5 \\
\hline Haircut & 1.28 & 8.51 & 0 & 103.5 \\
\hline Haircut $(+1)$ & 1.31 & 8.62 & 0 & 103.5 \\
\hline Haircut (+2) & 1.35 & 8.73 & 0 & 103.5 \\
\hline Haircut (+3) & 1.38 & 8.85 & 0 & 103.5 \\
\hline Haircut $(+4$ and +5$)$ & 2.92 & 13.19 & 0 & 148.3 \\
\hline Haircut $(+6$ and +7$)$ & 3.05 & 13.5 & 0 & 148.3 \\
\hline Haircut dummy (-1) & 0.03 & 0.18 & 0 & 1 \\
\hline Haircut dummy & 0.03 & 0.18 & 0 & 1 \\
\hline Haircut dummy $(+1)$ & 0.03 & 0.18 & 0 & 1 \\
\hline Haircut dummy (+2) & 0.03 & 0.18 & 0 & 1 \\
\hline Haircut dummy (+3) & 0.04 & 0.18 & 0 & 1 \\
\hline Haircut dummy $(+4$ and +5$)$ & 0.07 & 0.28 & 0 & 2 \\
\hline Haircut dummy $(+6$ and +7$)$ & 0.08 & 0.29 & 0 & 2 \\
\hline Official restr. $(-1)$ & 0.95 & 7.2 & 0 & 326.13 \\
\hline Official restr. & 0.95 & 7.2 & 0 & 326.13 \\
\hline Official restr. $(+1)$ & 0.98 & 7.3 & 0 & 326.13 \\
\hline Official restr. $(+2)$ & 1.01 & 7.4 & 0 & 326.13 \\
\hline Official restr. $(+3)$ & 1.03 & 7.51 & 0 & 326.13 \\
\hline Official restr. (+4 and 5) & 2.03 & 9.3 & 0 & 326.13 \\
\hline Official restr. (+6 and 7$)$ & 2.11 & 9.56 & 0 & 326.13 \\
\hline Official restr. dummy $(-1)$ & 0.08 & 0.28 & 0 & 1 \\
\hline Official restr. dummy & 0.08 & 0.28 & 0 & 1 \\
\hline Official restr. dummy $(+1)$ & 0.09 & 0.28 & 0 & 1 \\
\hline Official restr. dummy $(+2)$ & 0.09 & 0.28 & 0 & 1 \\
\hline Official restr. dummy $(+3)$ & 0.09 & 0.29 & 0 & 1 \\
\hline Official restr. dummy ( +4 and 5) & 0.19 & 0.44 & 0 & 2 \\
\hline Official restr. dummy (+6 and 7) & 0.2 & 0.45 & 0 & 2 \\
\hline FMSP & 10.39 & 4.02 & 0 & 21 \\
\hline Credit index & 39.27 & 17.24 & 4.6 & 93.1 \\
\hline Public debt to GDP & 57.36 & 56.29 & 0 & 789.83 \\
\hline Per capita GDP (log) & 8.93 & 5.64 & 3.91 & 27.62 \\
\hline GDP real growth & 3.84 & 6.71 & -62.08 & 106.28 \\
\hline (log) Popolation & 16.1 & 1.44 & 12.01 & 21.06 \\
\hline Reserves to imports & 1.01 & 5.27 & 0 & 95.28 \\
\hline Inflation & 44.12 & 515.05 & -13.06 & 23773.1 \\
\hline Current Account to GDP & -2.96 & 11.38 & -242.19 & 106.84 \\
\hline Political Risk & 59.25 & 12.25 & 0 & 89.13 \\
\hline Chief executive years in office & 8.61 & 8.49 & 0 & 47 \\
\hline Fitch & 0.11 & 0.31 & 0 & 1 \\
\hline Moody's & 0.09 & 0.29 & 0 & 1 \\
\hline Standard and Poor's & 0.16 & 0.36 & 0 & 1 \\
\hline
\end{tabular}


Table A4: Credit rating correlations

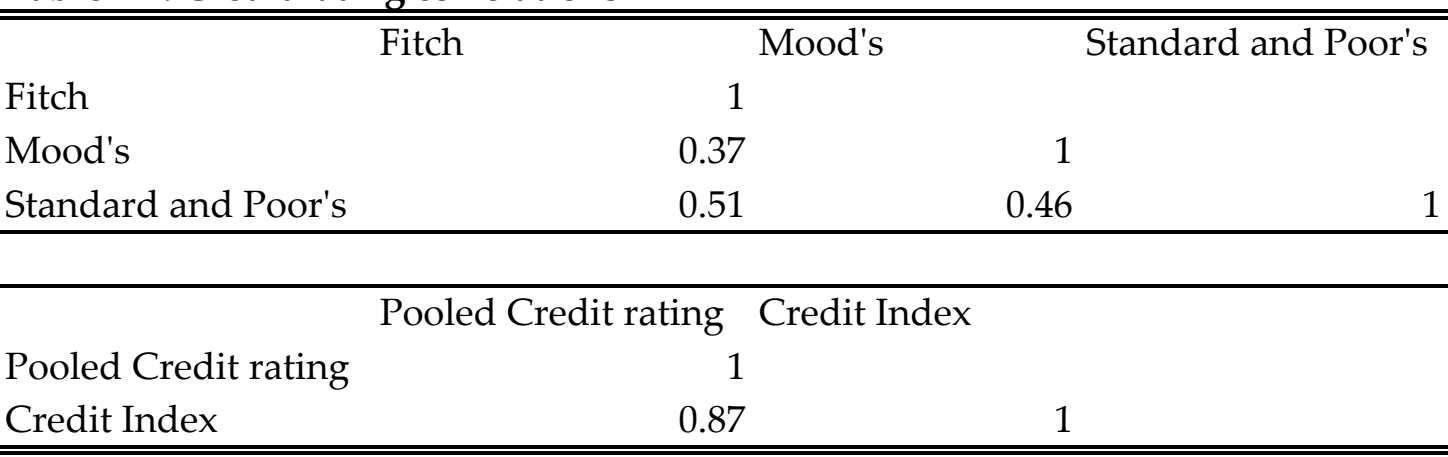


Table A5: Haircuts and Credit Rating, 1990-2013, Ordered probit

\begin{tabular}{|c|c|c|c|c|c|c|c|c|}
\hline & $(1)$ & $(2)$ & $(3)$ & $(4)$ & $(5)$ & $(6)$ & $(7)$ & $(8)$ \\
\hline Haircut dummy (-1) & $\begin{array}{c}-0.930^{* * *} \\
(-4.608)\end{array}$ & & $\begin{array}{c}-0.733^{* *} \\
(-2.465)\end{array}$ & $\begin{array}{c}-0.971^{* *} \\
(-2.070)\end{array}$ & $\begin{array}{l}-0.565^{*} \\
(-1.832)\end{array}$ & $\begin{array}{c}-1.067^{* *} \\
(-2.295)\end{array}$ & $\begin{array}{l}-0.650^{* *} \\
(-2.092)\end{array}$ & $\begin{array}{c}-1.289^{* * *} \\
(-2.838)\end{array}$ \\
\hline Haircut dummy & $\begin{array}{l}-1.504^{* * *} \\
(-10.225)\end{array}$ & & $\begin{array}{c}-1.707^{* * *} \\
(-8.460)\end{array}$ & $\begin{array}{r}-2.338^{* * *} \\
(-4.531)\end{array}$ & $\begin{array}{c}-1.252^{* * *} \\
(-5.049)\end{array}$ & $\begin{array}{c}-1.990^{* * *} \\
(-5.457)\end{array}$ & $\begin{array}{c}-1.469^{* * *} \\
(-5.830)\end{array}$ & $\begin{array}{c}-2.228^{* * *} \\
(-5.925)\end{array}$ \\
\hline Haircut dummy $(+1)$ & $\begin{array}{c}-1.924^{* * *} \\
(-8.870)\end{array}$ & & $\begin{array}{c}-1.579^{* * *} \\
(-2.768)\end{array}$ & $\begin{array}{c}-2.383^{* * *} \\
(-5.127)\end{array}$ & $\begin{array}{l}-1.442^{* *} \\
(-2.268)\end{array}$ & $\begin{array}{c}-2.480^{* * *} \\
(-5.722)\end{array}$ & $\begin{array}{l}-1.337^{*} \\
(-1.908)\end{array}$ & $\begin{array}{c}-2.748^{* * *} \\
(-6.464)\end{array}$ \\
\hline Haircut dummy (+2) & & & & & $\begin{array}{c}-0.830 \\
(-1.413)\end{array}$ & $\begin{array}{c}-1.277^{* *} \\
(-2.413)\end{array}$ & $\begin{array}{c}-0.661 \\
(-1.066)\end{array}$ & $\begin{array}{l}-1.361^{* *} \\
(-2.513)\end{array}$ \\
\hline Haircut dummy (+3) & & & & & $\begin{array}{c}-0.651 \\
(-1.080)\end{array}$ & $\begin{array}{c}-0.153 \\
(-0.141)\end{array}$ & $\begin{array}{c}-0.329 \\
(-0.527)\end{array}$ & $\begin{array}{c}-0.309 \\
(-0.295)\end{array}$ \\
\hline Haircut dummy (+4 \& 5) & & & & & & & $\begin{array}{l}-1.014^{*} \\
(-1.931)\end{array}$ & $\begin{array}{c}0.575 \\
(0.911)\end{array}$ \\
\hline Haircut dummy (+6 \& 7) & & & & & & & $\begin{array}{c}-0.141 \\
(-0.380)\end{array}$ & $\begin{array}{c}-1.871^{* * *} \\
(-4.833)\end{array}$ \\
\hline Haircut (-1) & & $\begin{array}{c}-0.017^{* * *} \\
(-3.221)\end{array}$ & $\begin{array}{c}-0.006 \\
(-0.801)\end{array}$ & $\begin{array}{c}-0.006 \\
(-0.778)\end{array}$ & $\begin{array}{c}-0.008 \\
(-1.106)\end{array}$ & $\begin{array}{c}-0.005 \\
(-0.646)\end{array}$ & $\begin{array}{c}-0.006 \\
(-0.852)\end{array}$ & $\begin{array}{c}-0.003 \\
(-0.315)\end{array}$ \\
\hline Haircut & & $\begin{array}{c}-0.020^{* * *} \\
(-4.838)\end{array}$ & $\begin{array}{c}0.005 \\
(1.620)\end{array}$ & $\begin{array}{c}0.010 \\
(1.417)\end{array}$ & $\begin{array}{c}-0.000 \\
(-0.018)\end{array}$ & $\begin{array}{c}0.008 \\
(1.232)\end{array}$ & $\begin{array}{c}0.003 \\
(0.682)\end{array}$ & $\begin{array}{c}0.011^{*} \\
(1.745)\end{array}$ \\
\hline Haircut $(+1)$ & & $\begin{array}{c}-0.037^{* * *} \\
(-4.516)\end{array}$ & $\begin{array}{c}-0.009 \\
(-0.753)\end{array}$ & $\begin{array}{c}-0.000 \\
(-0.010)\end{array}$ & $\begin{array}{c}-0.010 \\
(-0.793)\end{array}$ & $\begin{array}{c}0.001 \\
(0.090)\end{array}$ & $\begin{array}{c}-0.008 \\
(-0.624)\end{array}$ & $\begin{array}{l}0.013^{* *} \\
(2.488)\end{array}$ \\
\hline Haircut (+2) & & & & & $\begin{array}{c}-0.003 \\
(-0.266)\end{array}$ & $\begin{array}{c}-0.002 \\
(-0.200)\end{array}$ & $\begin{array}{c}-0.003 \\
(-0.277)\end{array}$ & $\begin{array}{c}0.000 \\
(0.011)\end{array}$ \\
\hline Haircut (+3) & & & & & $\begin{array}{c}-0.001 \\
(-0.089)\end{array}$ & $\begin{array}{c}-0.009 \\
(-0.652)\end{array}$ & $\begin{array}{c}-0.005 \\
(-0.334)\end{array}$ & $\begin{array}{c}-0.009 \\
(-0.580)\end{array}$ \\
\hline Haircut (+4 \& 5) & & & & & & & $\begin{array}{c}-0.001 \\
(-0.055)\end{array}$ & $\begin{array}{c}-0.021 \\
(-1.237)\end{array}$ \\
\hline Haircut (+6 \& 7) & & & & & & & $\begin{array}{c}-0.007 \\
(-0.646)\end{array}$ & $\begin{array}{c}0.008 \\
(0.703)\end{array}$ \\
\hline Public debt to GDP & & & & $\begin{array}{c}-0.011^{* *} \\
(-2.371)\end{array}$ & & $\begin{array}{l}-0.009^{* *} \\
(-2.009)\end{array}$ & & $\begin{array}{l}-0.010^{*} \\
(-1.871)\end{array}$ \\
\hline Per capita GDP (log) & & & & $\begin{array}{c}0.056^{* * *} \\
(3.380)\end{array}$ & & $\begin{array}{c}0.050^{* * *} \\
(3.002)\end{array}$ & & $\begin{array}{c}0.044^{* * *} \\
(2.760)\end{array}$ \\
\hline GDP real growth & & & & $\begin{array}{c}0.020 \\
(0.924)\end{array}$ & & $\begin{array}{c}0.016 \\
(0.694)\end{array}$ & & $\begin{array}{c}0.016 \\
(0.560)\end{array}$ \\
\hline (log) Popolation & & & & $\begin{array}{c}0.287^{* * *} \\
(4.060)\end{array}$ & & $\begin{array}{c}0.265^{* * *} \\
(3.657)\end{array}$ & & $\begin{array}{c}0.220^{* * *} \\
(2.873)\end{array}$ \\
\hline Reserves to imports & & & & $\begin{array}{c}0.005 \\
(0.684)\end{array}$ & & $\begin{array}{c}0.003 \\
(0.384)\end{array}$ & & $\begin{array}{c}0.001 \\
(0.126)\end{array}$ \\
\hline Inflation & & & & $\begin{array}{c}-6.485^{* * *} \\
(-4.263)\end{array}$ & & $\begin{array}{c}-6.454^{* * *} \\
(-4.214)\end{array}$ & & $\begin{array}{c}-6.382^{* * *} \\
(-4.047)\end{array}$ \\
\hline Current Account to GDP & & & & $\begin{array}{c}0.046^{* * *} \\
(4.596)\end{array}$ & & $\begin{array}{c}0.045^{* * *} \\
(4.156)\end{array}$ & & $\begin{array}{c}0.046^{* * *} \\
(3.730)\end{array}$ \\
\hline (Absence of) Political risk & & & & $\begin{array}{c}0.130^{* * *} \\
(6.803)\end{array}$ & & $\begin{array}{c}0.129^{* * *} \\
(6.233)\end{array}$ & & $\begin{array}{c}0.125^{* * *} \\
(4.809)\end{array}$ \\
\hline Years in Office & & & & $\begin{array}{c}0.003 \\
(0.321)\end{array}$ & & $\begin{array}{c}0.002 \\
(0.134)\end{array}$ & & $\begin{array}{c}0.001 \\
(0.096)\end{array}$ \\
\hline
\end{tabular}


Fitch

$-0.146$

$(-1.159)$

Moody's

Standard and Poor's
$-0.014$

$(-0.144)$

$-0.396^{* * *}$

$(-3.311)$
$-0.104$

$(-0.719)$

0.053

(0.537)

$-0.439^{* * *}$

$(-3.279)$
$-0.027$

$(-0.168)$

0.096

$(0.851)$

$-0.596^{* * *}$

(-3.978)

\begin{tabular}{lrrrrrrrr} 
Observations & 891 & 891 & 891 & 617 & 790 & 537 & 586 & 365 \\
\hline \hline Robust t-statistics in parentheses ${ }^{* * *} \mathrm{p}<0.01^{* *} \mathrm{p}<0.05^{*} \mathrm{p}<0.1$ & & & &
\end{tabular} 


$\begin{array}{llllll}(1) & (2) & (3) & (4) & (5) & (6)\end{array}$

$(7) \quad(8)$

$\begin{array}{lc}\text { Off. Restr. dummy }(-1) & -0.858^{* * *} \\ & (-6.979) \\ \text { Off. Restr. dummy } & -1.063^{* * *} \\ & (-6.083) \\ \text { Off. Restr. dummy (+1) } & -1.256^{* * *} \\ & (-5.554) \\ \text { Off. Restr. dummy (+2) } & \end{array}$

Off. Restr. dummy (+3)

Off. Restr dummy (+4 \& 5)

Off. Restr dummy (+6 \& 7)

Official Restr (-1)

Official Restr

Official Restr (+1)

Official Restr (+2)

Official Restr (+3)

Official Restr (+4 \& 5)

Official Restr (+6 \& 7)

Public debt to GDP

Per capita GDP (log)

GDP real growth

(log) Popolation

Reserves to imports

Inflation

Current Account to GDP

(Absence of) Political risk

Years in Office

$$
\begin{array}{cccccc}
-0.872^{* * *} & -0.719^{* *} & -0.823^{* * *} & -0.822^{* *} & -0.698^{* * *} & -1.133^{* *} \\
(-6.242) & (-2.361) & (-5.669) & (-2.471) & (-3.523) & (-2.040) \\
-1.029^{* * *} & -0.473^{*} & -0.818^{* * *} & -0.344 & -1.583^{* * *} & -1.190^{*} \\
(-5.255) & (-1.753) & (-3.648) & (-1.093) & (-3.894) & (-1.893) \\
-1.147^{* * *} & -0.731^{* *} & -1.074^{* * *} & -0.714^{*} & -1.428^{* * *} & -2.508^{* * *} \\
(-4.734) & (-2.105) & (-4.022) & (-1.915) & (-4.014) & (-4.015)
\end{array}
$$$$
\begin{array}{llll}
-0.577^{* * *} & -0.227 & -0.451^{*} & 0.247
\end{array}
$$$$
\begin{array}{llll}
(-2.813) & (-0.549) & (-1.705) & (0.482)
\end{array}
$$$$
\begin{array}{llll}
-0.262 & -1.229^{* * *} & -0.428 & -1.062
\end{array}
$$$$
\begin{array}{llll}
(-0.837) & (-2.807) & (-1.197) & (-1.410)
\end{array}
$$$$
-0.019-1.097
$$$$
(-0.051) \quad(-1.466)
$$$$
0.043-0.812^{* *}
$$$$
(0.164) \quad(-2.057)
$$

$$
\begin{array}{lllllll}
-0.011^{*} & 0.001 & 0.002 & 0.001 & 0.002 & -0.003 & 0.003
\end{array}
$$$$
\begin{array}{lllllll}
(-1.730) & (0.458) & (0.301) & (0.373) & (0.226) & (-0.306) & (0.147)
\end{array}
$$$$
\begin{array}{lllllll}
-0.050^{* * *} & -0.006 & -0.048^{* * *} & -0.007 & -0.050^{* * *} & 0.155^{* * *} & -0.040
\end{array}
$$$$
\begin{array}{llllllll}
(-3.009) & (-0.559) & (-6.158) & (-0.474) & (-5.277) & (2.593) & (-0.393)
\end{array}
$$$$
\begin{array}{lllllll}
-0.059^{* * *} & -0.013 & -0.025 & -0.016 & -0.028 & 0.060^{* *} & 0.185^{* * *}
\end{array}
$$$$
\begin{array}{llllllll}
(-4.425) & (-0.828) & (-1.021) & (-0.957) & (-1.054) & (2.509) & (2.888)
\end{array}
$$$$
\begin{array}{llll}
-0.021 & -0.026 & -0.019 * & -0.005
\end{array}
$$$$
\begin{array}{llll}
(-1.562) & (-1.168) & (-1.730) & (-0.263)
\end{array}
$$$$
\begin{array}{llll}
-0.018^{* *} & 0.002 & -0.019 * * & -0.018
\end{array}
$$$$
\begin{array}{llll}
(-2.117) & (0.145) & (-2.017) & (-0.948)
\end{array}
$$$$
-0.014 \quad 0.003
$$$$
(-1.335) \quad(0.121)
$$$$
-0.025^{* * *} 0.040^{* *}
$$$$
(-2.614) \quad(2.183)
$$

$-0.015^{* * *}$

$(-4.059)$

$0.039^{* * *}$

(3.395)

$-0.026$

(-1.022)

$0.279^{* * *}$

(5.563)

$0.019^{* * *}$

(2.678)

$-9.758^{* * *}$

(-7.236)

$0.046^{* * *}$

(4.337)

$0.105^{* * *}$

(5.683)

$0.026^{* * *}$

(2.663) 
Fitch

Moody's

Standard and Poor's

$-0.010$

$(-0.090)$

$-0.060$

$(-0.619)$

$-0.321^{* * *}$

$(-2.692)$

Robust t-statistics in parentheses ${ }^{* * *} \mathrm{p}<0.01,{ }^{* *} \mathrm{p}<0.05,{ }^{*} \mathrm{p}<0.1$

\begin{tabular}{lllllllll} 
Observations & 739 & 739 & 739 & 494 & 640 & 409 & 425 & 239 \\
\hline \hline
\end{tabular}

\begin{tabular}{lllllllll} 
Observations & 739 & 739 & 739 & 494 & 640 & 409 & 425 & 239 \\
\hline \hline
\end{tabular}

\begin{tabular}{lllllllll} 
Observations & 739 & 739 & 739 & 494 & 640 & 409 & 425 & 239 \\
\hline \hline
\end{tabular}

\begin{tabular}{lllllllll} 
Observations & 739 & 739 & 739 & 494 & 640 & 409 & 425 & 239 \\
\hline \hline
\end{tabular}

\begin{tabular}{lllllllll} 
Observations & 739 & 739 & 739 & 494 & 640 & 409 & 425 & 239 \\
\hline \hline
\end{tabular}

0.012

$(0.069)$

$-0.100$

$(-0.635)$

$-0.316^{*}$

(-1.738) 